\title{
Real-time measurements of ammonia, acidic trace gases and water-soluble inorganic aerosol species at a rural site in the Amazon Basin
}

\author{
I. Trebs ${ }^{1}$, F. X. Meixner ${ }^{1}$, J. Slanina ${ }^{2}$, R. Otjes ${ }^{2}$, P. Jongejan ${ }^{2}$, and M. O. Andreae ${ }^{1}$ \\ ${ }^{1}$ Max Planck Institute for Chemistry, Biogeochemistry Department, P. O. Box 3060, 55020 Mainz, Germany \\ ${ }^{2}$ Energy Research Center of the Netherlands, Department of Air Quality, 1755 ZG Petten, The Netherlands
}

Received: 5 December 2003 - Published in Atmos. Chem. Phys. Discuss.: 19 February 2004

Revised: 18 June 2004 - Accepted: 18 June 2004 - Published: 28 June 2004

\begin{abstract}
We measured the mixing ratios of ammonia $\left(\mathrm{NH}_{3}\right)$, nitric acid $\left(\mathrm{HNO}_{3}\right)$, nitrous acid (HONO), hydrochloric acid $(\mathrm{HCl})$, sulfur dioxide $\left(\mathrm{SO}_{2}\right)$ and the corresponding water-soluble inorganic aerosol species, ammonium $\left(\mathrm{NH}_{4}^{+}\right)$, nitrate $\left(\mathrm{NO}_{3}^{-}\right)$, nitrite $\left(\mathrm{NO}_{2}^{-}\right)$, chloride $\left(\mathrm{Cl}^{-}\right)$and sulfate $\left(\mathrm{SO}_{4}^{2-}\right)$, and their diel and seasonal variations at a pasture site in the Amazon Basin (Rondônia, Brazil). This study was conducted within the framework of LBA-SMOCC (Large Scale Biosphere Atmosphere Experiment in Amazonia Smoke Aerosols, Clouds, Rainfall and Climate: Aerosols from Biomass Burning Perturb Global and Regional Climate). Sampling was performed from 12 September to 14 November 2002, extending from the dry season (extensive biomass burning activity), through the transition period to the wet season (background conditions). Measurements were made continuously using a wet-annular denuder (WAD) in combination with a Steam-Jet Aerosol Collector (SJAC) followed by suitable on-line analysis. A detailed description and verification of the inlet system for simultaneous sampling of soluble gases and aerosol compounds is presented. Overall measurement uncertainties of the ambient mixing ratios usually remained below $15 \%$. The limit of detection (LOD) was determined for each single data point measured during the field experiment. Median LOD values ( $3 \sigma$-definition) were $\leq 0.015 \mathrm{ppb}$ for acidic trace gases and aerosol anions and $\leq 0.118 \mathrm{ppb}$ for $\mathrm{NH}_{3}$ and aerosol $\mathrm{NH}_{4}^{+}$. Mixing ratios of acidic trace gases remained below $1 \mathrm{ppb}$ throughout the measurement period, while $\mathrm{NH}_{3}$ levels were an order of magnitude higher. Accordingly, mixing ratios of $\mathrm{NH}_{4}^{+}$exceeded those of other inorganic aerosol contributors by a factor of 4 to 10 . During the wet season, mixing ratios decreased by nearly a factor of 3 for all compounds com-
\end{abstract}

Correspondence to: I. Trebs

(ivonne@mpch-mainz.mpg.de) pared to those observed when intensive biomass burning took place. Additionally, N-containing gas and aerosol species featured pronounced diel variations. This is attributed to strong relative humidity and temperature variations between day and night as well as to changing photochemistry and stability conditions of the planetary boundary layer. HONO exhibited a characteristic diel cycle with high mixing ratios at nighttime and was not completely depleted by photolysis during daylight hours.

\section{Introduction}

Every year, large emissions of aerosols and trace gases occur during the dry season (May through September) in the Amazon Basin from widespread biomass burning activity. Smoke from biomass burning leads to a significant increase in cloud condensation nuclei $(\mathrm{CCN})$ concentration causing alteration of cloud properties. This is likely to have considerable impact on the large-scale dynamics of the atmosphere (Andreae et al., 2002; Roberts et al., 2001). During the wet season, however, background conditions resemble $\mathrm{CCN}$ concentrations more typical of marine locations than most continental sites (Roberts et al., 2001). Both, water-soluble inorganic aerosol species and soluble gases are expected to play a major role in the nucleation and growth of cloud droplets under polluted as well as under clean conditions.

Ammonia $\left(\mathrm{NH}_{3}\right)$, in the tropics mostly emitted by combustion processes, volatilization from manure and fertilizer application, plays a key role in neutralizing acidic atmospheric compounds (Asman et al., 1998). Due to heterogeneous reactions involving gaseous $\mathrm{NH}_{3}$ as well as sulfur dioxide $\left(\mathrm{SO}_{2}\right)$, non-volatile aerosol constituents like $\left(\mathrm{NH}_{4}\right)_{2} \mathrm{SO}_{4}$ and $\mathrm{NH}_{4} \mathrm{HSO}_{4}$ can be formed. 
Table 1. Overview of sampling methods for $\mathrm{NH}_{3}$, acidic trace gases and inorganic aerosol species.

\begin{tabular}{|c|c|c|c|}
\hline Method & Example & Measured species & References \\
\hline Filter & $\begin{array}{l}\text { Impregnated filters, Teflon and } \\
\text { nylon filters in series }\end{array}$ & $\begin{array}{l}\mathrm{NH}_{3}, \mathrm{HNO}_{3} \text {, aerosol } \mathrm{NH}_{4}^{+} \\
\mathrm{NO}_{3}^{-}, \mathrm{Cl}^{-} \text {and } \mathrm{SO}_{4}^{2-}\end{array}$ & $\begin{array}{l}\text { Appel et al., 1980; Appel et al., 1981; } \\
\text { Cadle et al., 1982; Parrish et al., 1986; } \\
\text { Galasyn et al., 1987; Solomon et al., 1988; } \\
\text { Appel et al., } 1991\end{array}$ \\
\hline Denuder \& filter & Denuder-filter pack (DFP) & $\begin{array}{l}\mathrm{NH}_{3}, \mathrm{HNO}_{3}, \mathrm{HONO}, \mathrm{HCl}, \mathrm{SO}_{2}, \\
\text { aerosol } \mathrm{NH}_{4}^{+}, \mathrm{NO}_{3}^{-}, \mathrm{Cl}^{-} \text {and } \mathrm{SO}_{4}^{2-}\end{array}$ & $\begin{array}{l}\text { Kitto and Harrison, 1992; Harrison et al., 1996; } \\
\text { Danalatos and Glavas, 1999; Possanzini et al., } 1999\end{array}$ \\
\hline \multirow[t]{4}{*}{ Diffusion denuder } & Dry-coated diffusion denuder & $\mathrm{NH}_{3}, \mathrm{HNO}_{3}, \mathrm{HONO}, \mathrm{HCl}$ and $\mathrm{SO}_{2}$ & $\begin{array}{l}\text { Eatough et al., 1985; Durham et al., 1987; } \\
\text { Marshall and Dimmock, } 1992\end{array}$ \\
\hline & Wet-effluent diffusion denuder & $\mathrm{NH}_{3}, \mathrm{HNO}_{3}, \mathrm{HONO}, \mathrm{HCl}$ and $\mathrm{SO}_{2}$ & $\begin{array}{l}\text { Simon et al., 1991; Vecera and Dasgupta, 1991; } \\
\text { Taira and Kanda, 1993; Buhr et al., 1995; } \\
\text { Zellweger et al., } 1999\end{array}$ \\
\hline & Wet-annular denuder & $\mathrm{NH}_{3}, \mathrm{HNO}_{3}, \mathrm{HONO}, \mathrm{HCl}$ and $\mathrm{SO}_{2}$ & $\begin{array}{l}\text { Keuken et al., 1988; Wyers et al., 1993; } \\
\text { Allegrini et al., 1994; Slanina and Wyers, 1994; } \\
\text { Oms et al., 1996; Jongejan et al., } 1997\end{array}$ \\
\hline & AiRRmonia & $\mathrm{NH}_{3}$ & Erisman et al., 2001 \\
\hline Diffusion scrubber & $\begin{array}{l}\text { Diffusion scrubber and } \\
\text { mist chamber }\end{array}$ & $\begin{array}{l}\mathrm{NH}_{3}, \mathrm{HNO}_{3}, \mathrm{HONO} \\
\mathrm{HCl} \text { and } \mathrm{SO}_{2}\end{array}$ & $\begin{array}{l}\text { Matusca et al., 1984; Cofer et al., 1985; } \\
\text { Philips and Dasgupta, 1987; Lindgren, 1992; } \\
\text { Lefer et al., 1999; Sanhueza and Garaboto, } 2002\end{array}$ \\
\hline Fluorescence & $\begin{array}{l}\text { Laser-photolysis fragment-fluorescence } \\
\text { (LPFF) and laser-fluorescence } \\
\text { derivatization }\end{array}$ & $\begin{array}{l}\mathrm{HONO}, \mathrm{HNO}_{3} \\
\mathrm{NH}_{3} \text {, aerosol } \mathrm{NH}_{4}^{+}\end{array}$ & $\begin{array}{l}\text { Rodgers and Davis, 1989; Papenbrock and Stuhl, 1990; } \\
\text { Papenbrock and Stuhl, 1991; Abbas and Tanner, 1981; } \\
\text { Rapsomanikis et al., } 1988\end{array}$ \\
\hline \multirow{3}{*}{ Spectroscopy } & Cavity ring-down spectroscopy & HONO & Wang and Zhang, 2000 \\
\hline & $\begin{array}{l}\text { Long path absorption } \\
\text { photometer (LOPAP) }\end{array}$ & HONO & Heland et al., 2001; Kleffmann et al., 2003 \\
\hline & Particle mass spectrometer & $\begin{array}{l}\text { aerosol } \mathrm{NH}_{4}^{+}, \mathrm{NO}_{3}^{-}, \mathrm{Cl}^{-} \\
\text {and } \mathrm{SO}_{4}^{2-} \text { and others }\end{array}$ & $\begin{array}{l}\text { Gard et al., 1997; Jayne et al., 2000; } \\
\text { Mallina et al., 2000; Lee et al., 2002; } \\
\text { Jimenez et al., 2003 }\end{array}$ \\
\hline \multirow[t]{5}{*}{$\begin{array}{l}\text { Aqueous-phase } \\
\text { aerosol collection }\end{array}$} & $\begin{array}{l}\text { Particle-into-liquid } \\
\text { sampler (PILS) }\end{array}$ & $\begin{array}{l}\text { aerosol } \mathrm{NH}_{4}^{+}, \mathrm{NO}_{3}^{-}, \\
\mathrm{NO}_{2}^{-}, \mathrm{Cl}^{-} \text {and } \mathrm{SO}_{4}^{2-}\end{array}$ & Weber et al., 2001; Orsini et al., 2003 \\
\hline & Particle collection system (PCS) & aerosol $\mathrm{NO}_{3}^{-}, \mathrm{NO}_{2}^{-}$ & $\begin{array}{l}\text { Simon and Dasgupta, 1995a; } \\
\text { Simon and Dasgupta, 1995b }\end{array}$ \\
\hline & $\begin{array}{l}\text { Vapor condensation aerosol } \\
\text { collector system (VCACS) }\end{array}$ & aerosol $\mathrm{NO}_{3}^{-}, \mathrm{NO}_{2}^{-}$ & Zellweger et al., 1999 \\
\hline & $\begin{array}{l}\text { Wet effluent frit (WEF) and } \\
\text { integrated collection and } \\
\text { vaporization cell (ICVC) }\end{array}$ & aerosol $\mathrm{NO}_{3}^{-}$ & Buhr et al., 1995; Stolzenburg and Hering, 2000 \\
\hline & Steam jet aerosol collector (SJAC) & $\begin{array}{l}\text { aerosol } \mathrm{NH}_{4}^{+}, \mathrm{NO}_{3}^{-}, \mathrm{NO}_{2}^{-}, \\
\mathrm{Cl}^{-} \text {and } \mathrm{SO}_{4}^{2-}\end{array}$ & Khlystov et al., 1995; Slanina et al., 2001 \\
\hline
\end{tabular}


Moreover, the abundance of semi-volatile aerosol species such as $\mathrm{NH}_{4} \mathrm{NO}_{3}$ and $\mathrm{NH}_{4} \mathrm{Cl}$ is strongly dependent on the gas phase precursors, $\mathrm{NH}_{3}, \mathrm{HNO}_{3}$ and $\mathrm{HCl}$. $\mathrm{NH}_{4} \mathrm{NO}_{3}$ is believed to form via reversible phase equilibrium with gaseous $\mathrm{NH}_{3}$ and $\mathrm{HNO}_{3}$ (Stelson \& Seinfeld, 1982). Comparably, gaseous $\mathrm{NH}_{3}$ and $\mathrm{HCl}$ are precursors for the reversible formation of $\mathrm{NH}_{4} \mathrm{Cl}$ (Pio and Harrison, 1987). These thermodynamic equilibria are strongly dependent on relative humidity and temperature, such that low temperature and high relative humidity will shift the equilibrium to the aerosol phase.

Nitrous acid (HONO) is of atmospheric importance due to its expected significant contribution to the production of $\mathrm{OH}$ radicals. Rapid HONO photolysis can lead to an integrated $\mathrm{OH}$ yield of up to $34 \%$ at daytime (Kleffmann et al., 2003 and references therein). The observation of persistent daytime HONO (up to $150 \mathrm{ppt}$ ) was found by several investigators and it is expected to be mainly formed due to heterogeneous reaction of $\mathrm{NO}_{2}$ with surface water (Harrison and Kitto, 1994; Zhou et al., 2002; Alicke et al., 2003; Aumont et al., 2003; Genfa et al., 2003; Kleffmann et al., 2003).

Since the 1970's, adequate sampling of gaseous compounds and related semi-volatile aerosol species was recognized as a significant problem, especially with respect to the collection of $\mathrm{HNO}_{3}$, nitrate $\left(\mathrm{NO}_{3}^{-}\right)$, but also $\mathrm{NH}_{3}$, ammonium $\left(\mathrm{NH}_{4}^{+}\right)$, chloride $\left(\mathrm{Cl}^{-}\right)$and sulfate $\left(\mathrm{SO}_{4}^{2-}\right)$ (Appel and Tokiwa, 1981; Appel et al., 1984; Slanina et al., 1992; Appel, 1993; Cheng and Tsai, 1997). In particular, $\mathrm{HNO}_{3}$ measurements without interferences are very difficult, since this molecule can readily absorb on surfaces of inlets (Appel et al., 1988; Neuman et al., 1999) and sampling substrates (e.g. filter materials) (Appel et al., 1984). Furthermore, desorption and re-evaporation of $\mathrm{HNO}_{3}$ from inlet surfaces or sampling substrates may considerably bias sampling results. The collection of aerosol species on filter materials without pre or after-stages to trap gaseous compounds leads to significant artifacts (Slanina et al., 2001). Long sampling times (hours to days) to collect sufficient aerosol on the filter material may result either in evaporation of semi-volatile aerosol species (negative artifact) or to collection of gaseous compounds (such as $\mathrm{NH}_{3}, \mathrm{HNO}_{3}, \mathrm{HCl}$ and $\mathrm{SO}_{2}$ ) which may be retained by filter media (positive artifact).

To date there are no reliable measurements of $\mathrm{NH}_{3}$ and acidic trace gases $\left(\mathrm{HNO}_{3}, \mathrm{HONO}, \mathrm{HCl}\right.$, and $\left.\mathrm{SO}_{2}\right)$ from the Amazon Basin, and in the past inorganic aerosol species were usually sampled by filter methods without accounting for possible artifacts. High temperatures and relative humidities (close to $100 \%$ at nighttime) are typical for this tropical region, which may significantly influence gas/aerosol partitioning processes. During the wet season, conditions usually remain very clean (low aerosol and trace gas concentrations are present) in contrast to the dry season when biomass burning takes place. For these reasons a method which provides continuous measurements with (a) high selectivity, (b) high time resolution (determination of diel variations for gas and aerosol compounds simultaneously), and (c) low detection limits is needed. Therefore, we applied the combination of a wet-annular denuder (WAD) and a Steam-Jet aerosol collector (SJAC) (Wyers et al., 1993; Slanina et al., 2001) followed by on-line analysis using ion chromatography (IC) and ammonium flow injection analysis (FIA). Here, we report the application of a sophisticated inlet system for simultaneous sampling of gas and aerosol species verified for potential sampling losses (particularly $\mathrm{HNO}_{3}$ ). Furthermore, an evaluation of the measurement performance of the instrument (with particular emphasis on measurement uncertainty and limit of detection) and first results of seasonal and diel variations of the measured species are presented. For this purpose, we selected exemplary data from a period within the dry season (17-20 September), to show the reliability of the measurements compared to studies that have been carried out, e.g., in the Northern Hemisphere. The main scope of this paper is to report and validate first real-time measurements of inorganic aerosol species simultaneously with their gaseous precursors in a tropical environment.

\section{Available measurement methods}

Table 1 gives an overview of the most common sampling methods for the collection of inorganic gas and aerosol species with selected references.

The filter-pack method, usually with Teflon, Nylon or impregnated filters in series, is the least accurate, but simplest and most commonly used sampling procedure (Appel, 1993). This technique is laborious, and suffers from long sampling times as well as possible interference due to oxidation of nitrites collected on nylon filters, which may positively bias $\mathrm{HNO}_{3}$ collection (Perrino et al., 1988). Also, evaporation of aerosol $\mathrm{NO}_{3}^{-}$from Teflon filters has been reported (Appel et al., 1981).

The most substantial approach for sampling a gas in the presence of corresponding aerosol particles is the denuder technique. Dry-coated diffusion denuders are reliable, but laborious and provide only long time-average concentration measurements (Dasgupta, 1993). These drawbacks were overcome by various other developments. $\mathrm{Si}$ mon et al. (1991) have proposed four different designs for wet effluent diffusion denuders coupled to ion chromatography systems with continuously renewed collection surfaces. Efficient retention of trace gases and a higher time resolution may be achieved by parallel-plate denuders coupled to on-line analysis. Keuken et al. (1989) developed an automated thermodenuder system for the determination of $\mathrm{NH}_{3}$ in ambient air. A device that is becoming increasingly popular is the so called WAD which has the ability to maintain near-quantitative collection efficiencies at high sampling rates within a compact design (Dasgupta, 1993). The first WAD operating in batch mode was reported by Keuken et al. (1988) and a continuously rotating annular denuder was 


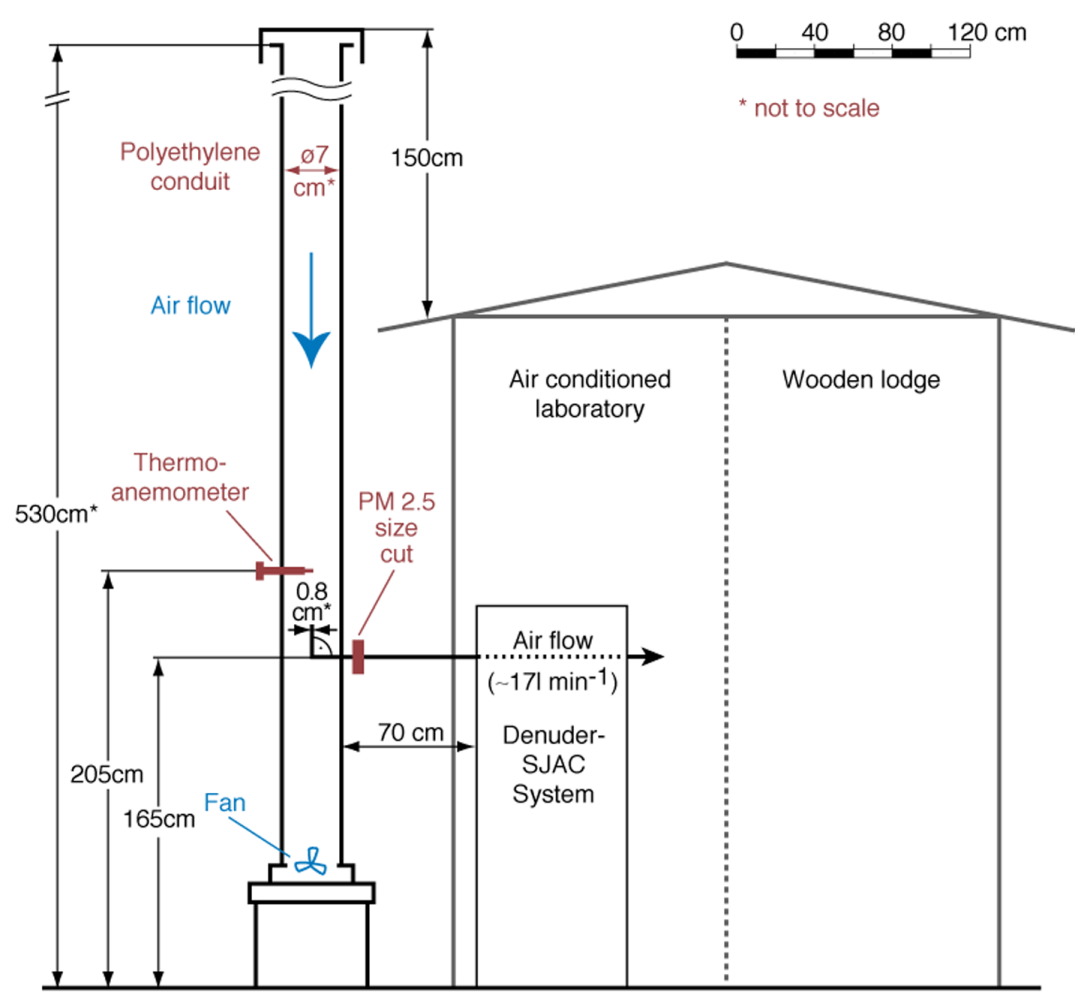

Fig. 1. Design and setup of the inlet system for real-time measurements of water-soluble gases and inorganic aerosol species at FNS during SMOCC 2002.

first described by Wyers et al. (1993). Diffusion scrubber and mist chamber techniques also provide measurements with higher time resolution and are less prone to artifacts.

The occurrence of artifacts during sampling of $\mathrm{HNO}_{3}$, but also $\mathrm{NH}_{3}$, has led to various intercomparison experiments (e.g. Spicer et al., 1982; Hering et al., 1988; Williams et al., 1992). In these studies, substantial discrepancies between different $\mathrm{HNO}_{3}$ measurement techniques were observed emphasizing the need of artifact-free methods for accurate measurements of atmospheric $\mathrm{HNO}_{3}$.

Problematic sampling of especially $\mathrm{HNO}_{3}$, but also $\mathrm{NH}_{3}$ has lead to the implementation of various intercomparison experiments (e.g. Spicer et al., 1982; Hering et al., 1988; Williams et al., 1992). In these studies, significant discrepancies between different $\mathrm{HNO}_{3}$ measurement techniques were observed which emphasized the need of artifact-free measurement methods for an accurate determination of $\mathrm{HNO}_{3}$ in the atmosphere.

Although the replacement of filter-based methods by continuous denuder devices and optical measurement techniques (also listed in Table 1) was a positive development in the last decade, usually these methods are only capable of measuring either one single compound or species of the same physical state (i.e. either gas or aerosol). The combination of new aqueous phase aerosol collectors with the denuder technique is up to date the only approach for the simultaneous collection of gas and aerosol species. Usually, these methods are continuous, followed by on-line analysis of the resulting aqueous solution. On-line IC has become the major analytical tool for these sampling systems, being able to measure ambient concentrations continuously in the low two-digit ppt range.

\section{Experimental}

\subsection{Site description}

Sampling was performed at a pasture site in the state of Rondônia, Brazil (Fazenda Nossa Senhora Aparecida, FNS, $10^{\circ} 45^{\prime} 44^{\prime \prime} \mathrm{S}, 62^{\circ} 21^{\prime} 27^{\prime \prime} \mathrm{W}, 315 \mathrm{~m}$ asl). Clearing of rain forest by fire in Rondônia has taken place since 1968, creating a typical "fishbone"-like pattern of plantations, pastures, degraded land and forest patches (see Andreae et al., 2002). The vegetation at FNS is dominated by grass (Brachiaria brizantha) with small patches of Brachiaria humidicola and very few isolated palms and bushes, and the site is used as a cattle ranch ( 200 "Blanco" cattle, Bos indicus hybrid). Nearby the site, flat hills $(300$ to $440 \mathrm{~m}$ ) are located at a distance of 3 to $4 \mathrm{~km}$. The pasture is a rural, non-pristine site, with a highway (BR 364) at a distance of $10 \mathrm{~km}$ to the northeast. The towns Ouro Preto d'Oeste ( $\sim 0800$ inhabitants) and Ji-Paraná ( $\sim 10000$ inhabitants $)$ are situated approximately $8 \mathrm{~km}$ and $40 \mathrm{~km}$ to the ENE and ESE of the site, respectively. 
The site is characterized by small seasonal temperature variations, ranging from $23-24^{\circ} \mathrm{C}$ at the end of the wet season (June/July) to $25-26^{\circ} \mathrm{C}$ during the dry season (September/October). Annual relative humidity values are high, with averages of about $70 \%$ in the dry season and $80 \%$ during the wet season. Prevailing wind speeds are relatively low (daily average $\sim 1.5 \mathrm{~m} \mathrm{~s}^{-1}$ ) with a minimum during nighttime. Precipitation in this region shows a seasonal cycle with lowest values in July and is highest from November to April (up to $\sim 300 \mathrm{~mm}$ per month) (Andreae et al., 2002). A detailed description of the history of the site can be found in Kirkman et al. (2002).

Instrumentation for sampling and on-line analysis was arranged in a wooden house with several air conditioned laboratories. The house was surrounded by a fence (distance to the house $\sim 10 \mathrm{~m}$ ) to prevent cattle from approaching the sampling and measurement location.

\subsection{Inlet system}

\subsubsection{Design}

The sampling performance of the wet-annular denuder/steam-jet aerosol collector (WAD/SJAC) and the quality of the on-line analysis are strongly dependent on environmental parameters (i.e. air temperature and relative humidity). In order to provide controlled conditions for sampling and particularly for IC and FIA (i.e. minimal fluctuations of temperature and relative humidity), it was necessary to place the instrumentation in an air conditioned laboratory. An inlet system mounted to the wall outside of the air conditioned laboratory was used to bring sample air to the instruments (Fig. 1). For the design of this inlet system, three major requirements had to be considered: (a) Minimizing gas phase wall losses (particularly $\mathrm{HNO}_{3}$ ), (b) Minimizing aerosol losses due to non-isokinetic sampling, and (c) providing a reasonable sampling fetch. To meet these requirements, air was sampled from $530 \mathrm{~cm}$ above ground $(150 \mathrm{~cm}$ above the roof of the house) through a vertical polyethylene conduit with an inner diameter of $7 \mathrm{~cm}$. The conduit was wrapped on the outside with aluminum tape to reduce daytime heating of the material. The air flow in the conduit was generated by a suction fan assembled in the conduit bottom. A sub-sample of the air was aspirated from the center of the conduit's cross section area at a flow rate of $\sim 171 \mathrm{~min}^{-1}$ (STP: $298.15 \mathrm{~K}$ and $1000 \mathrm{hPa}$ ) through a steel elbow $\left(90^{\circ}\right.$ angle of steel tubing, $\mathrm{d}=0.8 \mathrm{~cm}$, inner surface PFA Teflon coated) mounted inside the conduit (Fig. 1). The sampled air was then drawn through a PFA Teflon tubing connection $(\mathrm{d}=0.8 \mathrm{~cm}, \mathrm{l}=70 \mathrm{~cm})$ to the sampling system in the air conditioned laboratory. The PFA Teflon tubing inside the laboratory had a length of only $5 \mathrm{~cm}$ before entering the instrument and was insulated thoroughly to prevent condensation. During the field experiment, the steel elbow was replaced periodically with a pre-impactor
(PM 2.5 size cut; type 413, University Research Glassware, aluminum cyclone, PFA Teflon coated). Hence, aerosol samples of either PM $2.5\left(\mathrm{D}_{p}<2.5 \mu \mathrm{m}\right)$ or bulk aerosol fraction were collected in alternating cycles (1-3 days). Velocity, relative humidity and temperature of the air stream in the polyethylene conduit were continuously monitored (time resolution $1 \mathrm{~min}$ ) using a thermo-anemometer sensor (Velocicalc Plus 8386, TSI Instruments).

Neuman et al. (1999) tested different inlet materials for sampling $\mathrm{HNO}_{3}$ and found highest transmission efficiencies ( $\geq 95 \%$ ) for plastic materials at $22^{\circ} \mathrm{C}$ (e.g. PFA, TFE, FEP and $\mathrm{PVDF}$ ), whereas $\mathrm{HNO}_{3}$ loss on aluminum, steel or nylon materials was $\sim 85 \%$. Plastic materials, such as polycarbonate (Spicer and Schumacher, 1979), polyethylene and PVC, are generally known to have a low affinity to adsorb $\mathrm{HNO}_{3}$ vapor. During the EPA Atlanta Supersite Experiment (1999), PVC was used as inlet material for sampling $\mathrm{HNO}_{3}$ and HONO and proved to be satisfactory (Genfa et al., 2003). On the basis of these results, the polyethylene inlet conduit was considered to be appropriate for sampling of $\mathrm{HNO}_{3}$ and other soluble gases. Also, using Teflon coated aluminum cyclones as inlet under atmospheric conditions; Appel et al. (1988) observed transmission efficiencies for $\mathrm{HNO}_{3}$ not significantly different from $100 \%$. Nevertheless, to ensure the quality of our measurements, we present a theoretical verification of the applied inlet system in the following section.

\subsubsection{Sampling efficiency of the inlet system}

To minimize gas phase losses (particularly $\mathrm{HNO}_{3}$ ), laminar conditions in the conduit are necessary to avoid turbulence and to minimize the contact of the sampled air with the inlet walls. However, since simultaneous sampling of gases and aerosol species was intended, it was crucial to account for possible inlet losses of both, gases and aerosols. The required flow rate for the pre-impactor $(\mathrm{d}=0.8 \mathrm{~cm})$ was $\sim 171 \mathrm{~min}^{-1}$ (STP). The mean air velocity in the polyethylene conduit generated by the suction fan was adjusted to $\sim 1 \mathrm{~m} \mathrm{~s}^{-1}$ (Reynolds number $\operatorname{Re}_{\text {mean }} \sim 4500$ ) indicating the transition between laminar conditions and turbulence. This, in turn, led to slightly superisokinetic sampling at the entrance of the steel elbow and/or pre-impactor, since the mean air velocity at its entrance was around $8 \mathrm{~m} \mathrm{~s}^{-1}$. Aerosol losses due to non-isokinetic sampling were calculated using the equation of Belyaev and Levin (1974) (Hinds, 1999):

$$
\frac{\Delta c}{c_{0}}=1-\left(1+\left(\frac{v_{0}}{v}-1\right) \times\left(1-\frac{1}{1+\left(2+0.62 \times \frac{v}{v_{0}}\right) \times S t k}\right)\right)
$$

where $\Delta c / c_{0}$ is the relative aerosol loss between conduit and steel elbow and/or pre-impactor, $v_{0}$ is the air velocity in the conduit $\left(\mathrm{ms}^{-1}\right)$ (STP), $v$ is the air velocity in the steel elbow and/or pre-impactor $\left(\mathrm{m} \mathrm{s}^{-1}\right)$ (STP) and $S t k$ is the 


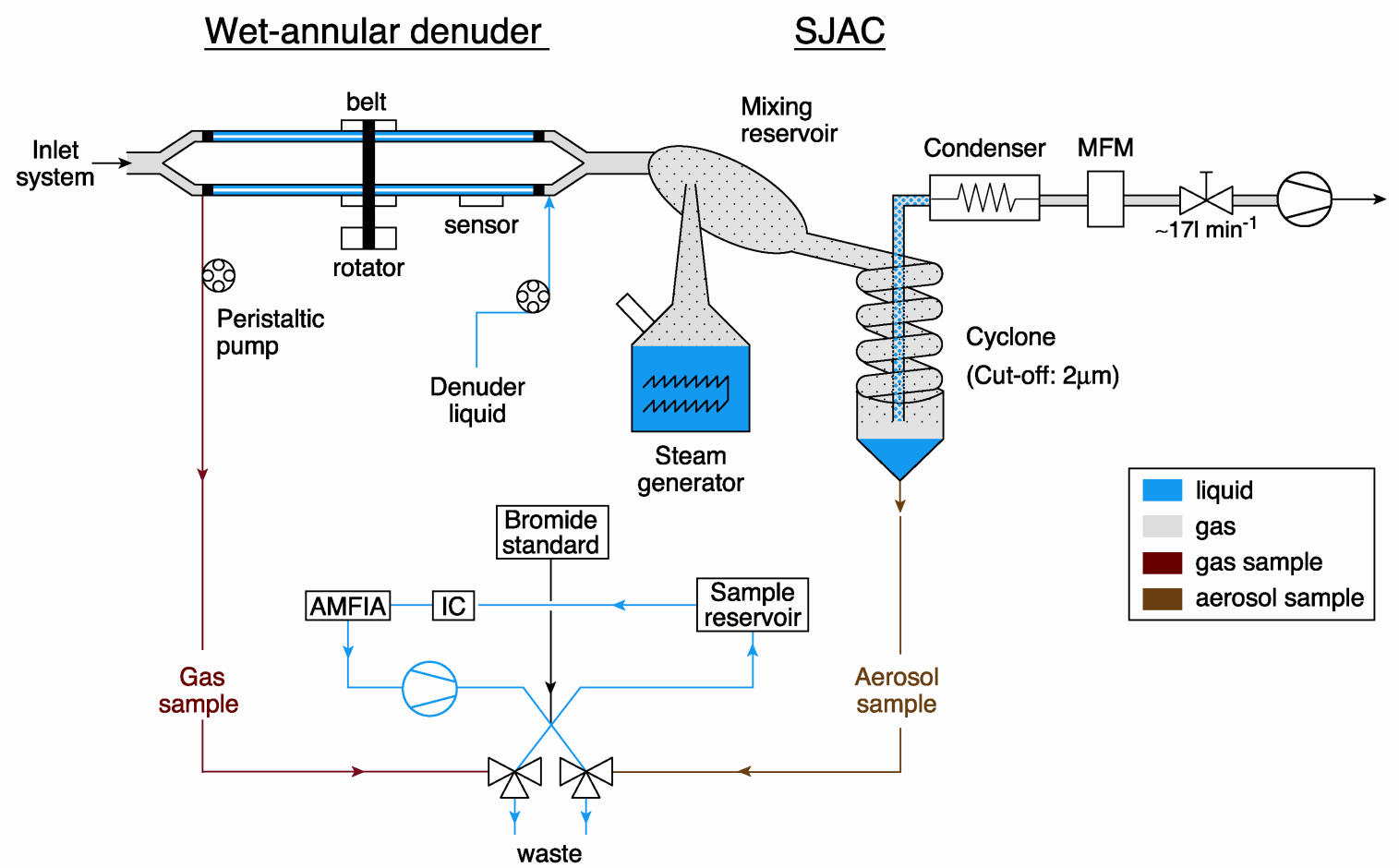

Fig. 2. Simplified sketch of the WAD/SJAC system including analytical part.

corresponding Stokes number. Aerosol losses $\left(\mathrm{D}_{P} \leq 2.5 \mu \mathrm{m}\right)$ were $\leq 3 \%$ for during the entire experiment, and are subsequently neglected.

To verify the performance of the inlet regarding the transmission of gaseous compounds, "worst case" wall losses were calculated for $\mathrm{HNO}_{3}$. Therefore, a hypothetical complete coating of the inner conduit surface with water droplets and aerosols, and a $\mathrm{HNO}_{3}$ uptake coefficient of $\gamma_{\mathrm{HNO}_{3}}=1$ (any molecule diffusing to the wall surface would be absorbed="worst case scenario") was assumed. The conduit was considered as a circular denuder tube with laminar flow conditions and hypothetical wall losses of $\mathrm{HNO}_{3}$ were calculated by application of the following equation (Gormley and Kennedy, 1949; equation modified):

$$
\begin{aligned}
& \frac{\Delta c}{c_{0}}=1- \\
& \left(0.8191 \times e^{-3.6568 \times \Delta}+0.0975 \times e^{-22.3 \times \Delta}+0.0325 \times e^{-57 \times \Delta}+\ldots\right)
\end{aligned}
$$

with

$$
\Delta=\frac{\pi \times D_{G} \times L_{C}}{Q_{C}}
$$

where $\Delta c / c_{0}$ denotes the relative gas phase loss, $D_{G}$ the $\mathrm{HNO}_{3}$ diffusion coefficient $\left(\mathrm{cm}^{2} \mathrm{~s}^{-1}\right), L_{C}$ the length of the conduit $(\mathrm{cm})$ and $Q_{C}$ the air flow in the conduit $\left(\mathrm{cm}^{3} \mathrm{~s}^{-1}\right)$ (STP). The $\mathrm{HNO}_{3}$ diffusion coefficient in air was experimentally determined by several investigators ranging from $0.04 \mathrm{~cm}^{2} \mathrm{~s}^{-1}$ to $0.121 \mathrm{~cm}^{2} \mathrm{~s}^{-1}$ (STP) (Braman et al., 1982; Eatough et al., 1985; Durham and Stockburger, 1986; and Deandrade et al., 1992). In this study, we used the highest value $\left(0.121 \mathrm{~cm}^{2} \mathrm{~s}^{-1}\right)$. Mean hypothetical "worst case" gas phase losses $\left(\gamma_{\mathrm{HNO}_{3}}=1\right)$ of $\leq 30 \%$ were derived for the conditions observed during the entire measurement period. However, Kirchner et al. (1990), van Doren et al. (1990) and Ponche et al. (1993) reported from laboratory studies $\gamma_{\mathrm{HNO}_{3}} \ll 1$ for the heterogeneous uptake of $\mathrm{HNO}_{3}$ by pure aqueous droplets (typically $\gamma_{\mathrm{HNO}_{3}}$ was $<0.2$ for $\mathrm{T}>260 \mathrm{~K}$ ). Taking into account atmospheric conditions and possible coating of the inner conduit walls with strong electrolytic aerosol mixtures, we consider a $\mathrm{HNO}_{3}$ uptake coefficient of $\gamma_{\mathrm{HNO}_{3}}=0.5$ as a conservative estimate, appropriate for our study. Therefore, theoretical mean gas phase $\mathrm{HNO}_{3}$ losses for the entire experiment were estimated to $\leq 15 \%$. This estimate is, however, based on the assumption of laminar flow in the conduit, whereas actual flow conditions during the experiment were characterized by $\operatorname{Re}_{\text {mean }} \sim 4500$ (see above), exceeding the laminar flow range $(\operatorname{Re} \leq 2300)$, but still at the lower end of the laminar-turbulent transition. Under (fully) turbulent conditions ( $\operatorname{Re}>10000)$, higher $\mathrm{HNO}_{3}$ losses $(>15 \%)$ have to be expected. Therefore, we performed some empirical verification tests. Occasionally, 
the complete inlet system (conduit and steel elbow and/or pre-impactor) was removed, resulting in sampling straight through the $70 \mathrm{~cm}$ long PFA Teflon tubing. During this procedure, $\mathrm{HNO}_{3}$ mixing ratios never significantly changed from "inlet system on" to "inlet system off", which supports our estimates of $\mathrm{HNO}_{3}$ wall losses $\leq 15 \%$.

\subsection{Sampling and analysis}

A detailed description of the WAD/SJAC and the analytical procedures is given elsewhere (Slanina et al., 2001; Wyers et al., 1993). A simplified sketch of the sampling system is shown in Fig. 2. The air flow through the instrument $\left(\sim 171 \mathrm{~min}^{-1}\right.$, STP) was generated by a scroll pump outside the wooden house and could be adjusted with a needle valve. The flow was measured continuously ( $1 \mathrm{~min}$ time resolution) with a mass flow meter (Bronkhorst, F-112ACHA-55-V). After the sample air passed the steel elbow and/or pre-impactor and the PFA Teflon tubing, it entered a horizontally aligned WAD that scavenges soluble gaseous species. Trace gases (such as $\mathrm{NH}_{3}, \mathrm{HNO}_{3}, \mathrm{HNO}_{2}, \mathrm{HCl}$ and $\mathrm{SO}_{2}$ ) were collected in a $10^{-4} \mathrm{M} \mathrm{NaHCO}_{3}$ absorption solution. The liquid input was controlled automatically by an infrared sensor and a switching valve and the liquid was continuously pumped out of the denuder at a flow rate of $0.5-0.6 \mathrm{ml} \mathrm{min}^{-1}$ by a peristaltic pump. The liquid effluent was collected in a sample reservoir ("gas sample", see Fig. 2). Artifacts due to evaporation of aerosol phase species in the WAD can be excluded because the characteristic time for formation/evaporation of $\mathrm{NH}_{4} \mathrm{NO}_{3}$ is $>10 \mathrm{~s}$ (Dlugi, 1993), while the mean residence time of the sample air in the WAD is $\sim 0.002$ s (annulus volume: 0.00181 , flow rate: $\sim 171 \mathrm{~min}^{-1}$ ).

After the WAD, the air entered a reservoir where it was mixed with steam of highly purified water. The supersaturation causes aerosol particles to grow rapidly (within $0.1 \mathrm{~s}$ ) into droplets of at least $2 \mu \mathrm{m}$ diameter. These droplets, containing the dissolved aerosol species were then collected in a cyclone (Khlystov et al., 1995). The cyclone effluent ("aerosol sample") was transferred into the sample reservoir by a peristaltic pump at a flow rate of $0.5-0.6 \mathrm{ml} \mathrm{min}^{-1}$.

Collection of liquid samples in the sample reservoir and the following analytical cycles were performed successively for gas and aerosol sample. On-line analyses were carried out using a mobile IC with suppressed conductivity detection. The system was operated with an HPLC separation column (Dionex, IonPac AS12A, $4 \mathrm{~mm}$ ) preceded by a guard column (Dionex, IonPac AG12A, $4 \times 50 \mathrm{~mm}$ ). Samples were injected via a $199 \mu \mathrm{l}$ loop into $2.7 \mathrm{mM} \mathrm{Na} \mathrm{CO}_{3}-0.3 \mathrm{mM}$ $\mathrm{NaHCO}_{3}$ eluent. Internal $\mathrm{Br}^{-}$standard addition using a peristaltic pump was performed continuously to calibrate the IC. The conductivity cell of the IC was temperature-stabilized at $30^{\circ} \mathrm{C}$ and therefore conductivity measurements were independent from room temperature.

Ammonium $\left(\mathrm{NH}_{4}^{+}\right)$was determined by FIA (Wyers et al., 1993). The general principle is the addition of $\mathrm{OH}^{-}$ions, converting $\mathrm{NH}_{4}^{+}$to $\mathrm{NH}_{3}$, which will then pass through a Teflon membrane and is taken up by highly purified water. Subsequent $\mathrm{NH}_{4}^{+}$-detection is based on conductometry. The conductivity cell of the FIA was not temperature controlled; therefore, conductivity measurements were dependent on temperature. Despite operating an air conditioner, diel temperature variations from $22^{\circ} \mathrm{C}$ at night to $30^{\circ} \mathrm{C}$ at daytime were observed in the laboratory. Fluctuations of the conductivity due to temperature changes in the air conditioned laboratory were corrected using:

Condcorr $=$ Cond $\times e^{(0.024 \times(20-T))}$

where Condcorr denotes the corrected conductivity value $(\mathrm{mV})$, Cond is the original measured conductivity $(\mathrm{mV})$ and $T$ is the observed temperature $\left({ }^{\circ} \mathrm{C}\right)$ in the laboratory. The FIA was calibrated once every week using standard solutions of $50 \mathrm{ppb}$ and $250 \mathrm{ppb} \mathrm{NH}_{4}^{+}$.

IC and FIA analyses were performed simultaneously for each sample. The analytical sample cycle was purged with ambient air after every run to avoid memory effects of the previous sample solution. The sampling system is fully automated and its software controls the sequence of sample injections and integrates detected peak areas. Cycle times for the successive analysis of "aerosol and gas sample" were set to $20 \mathrm{~min}$ (biomass burning season), $40 \mathrm{~min}$ (transition period) and $60 \mathrm{~min}$ (wet season).

Ambient mixing ratios for gas and aerosol species after IC analyses were determined using the following equation:

$m=\frac{m_{\mathrm{liq}} \times m_{\mathrm{Br}(\mathrm{std})} \times Q_{\mathrm{Br}} \times Q_{\mathrm{Br}} \times M_{\mathrm{air}}}{m_{\mathrm{Br}} \times Q_{\mathrm{air}} \times M_{i}}$,

where $m$ is the ambient mixing ratio (ppb), $m_{\text {liq }}$ is the mixing ratio of the compounds found in "aerosol or gas sample" (ppb), $m_{\mathrm{Br}(\mathrm{std})}$ is the mixing ratio of the $\mathrm{Br}^{-}$standard solution ( $\mathrm{ppb}$ ), $Q_{\mathrm{Br}}$ is the flow of the $\mathrm{Br}^{-}$standard solution which is mixed into the liquid sample $\left(\mathrm{kg} \mathrm{s}^{-1}\right), G$ is the factor to convert the molar weight of ionic compounds analyzed into the molecular weight of the corresponding trace gas (the factor is 1 for aerosol species). $M_{\text {air }}$ is the molar mass of air at $298.15 \mathrm{~K}$ and $1000 \mathrm{hPa}\left(24.774 \mathrm{~kg} \mathrm{kmol}^{-1}\right), m_{\mathrm{Br}}$ is the analyzed $\mathrm{Br}^{-}$mixing ratio (ppb), $Q_{\text {air }}$ is the air mass flow through the system $\left(\mathrm{kg} \mathrm{s}^{-1}\right)$ and $M_{i}$ is the molar weight of compound $\mathrm{i}\left(\mathrm{kg} \mathrm{kmol}^{-1}\right)$. This equation is also valid for calculating ambient mixing ratios of $\mathrm{NH}_{3}$ and aerosol $\mathrm{NH}_{4}^{+}$, except for parameters related to the $\mathrm{Br}^{-}$standard addition and replacing $Q_{\mathrm{Br}}$ by $Q_{\mathrm{S}}$, which is the liquid flow of "gas sample" $\left(\mathrm{NH}_{3}\right)$ or "aerosol sample" $\left(\mathrm{NH}_{4}^{+}\right)\left(\mathrm{kg} \mathrm{s}^{-1}\right)$.

\section{Results and discussion}

The sampling period was chosen from 12 September to 14 November 2002, covering extensive biomass burning activity during the dry season (12 to 23 September), an intermediate phase (transition period, 7 to 31 October) and clean 
Table 2. Standard deviations $\sigma_{x}$ contributing to the total measurement uncertainty $\sigma_{m}$. (index $x$ is the mixing ratio of the compounds found in "aerosol or gas sample" $\left(m_{\text {liq }}\right)$, the mixing ratio of the $\mathrm{Br}^{-}$standard solution $\left(m_{\mathrm{Br}(\mathrm{std})}\right)$, the flow of the $\mathrm{Br}^{-}$standard solution $\left(Q_{\mathrm{Br}}\right)$, the analyzed $\mathrm{Br}^{-}$mixing ratio $\left(m_{\mathrm{Br}}\right)$ or the air mass flow through the system $\left(Q_{\text {air }}\right)$, and index $m$ is the ambient mixing ratio).

\begin{tabular}{|c|c|c|c|}
\hline $\begin{array}{l}\text { Standard } \\
\text { deviations } \sigma_{x}\end{array}$ & Value/range & Source/determination & $\begin{array}{l}\text { Mean contri- } \\
\text { bution to } \sigma_{m}\end{array}$ \\
\hline \multicolumn{4}{|l|}{ IC analyses } \\
\hline$\overline{\sigma_{m l i q}}$ & $0.002-6.8 \mathrm{ppb}$ & $5 \%$ of $m_{\text {liq }}$, analysis of standard solutions & $18 \%$ \\
\hline$\sigma_{m \mathrm{Br}(\mathrm{std})}$ & $20 \mathrm{ppb}$ & $\begin{array}{l}2 \% \text { of } m_{\mathrm{Br}(\mathrm{std})} \text {, estimated uncertainty of } \\
\text { weighting procedures for creating } \mathrm{Br}^{-} \text {stan- } \\
\text { dard solutions }\end{array}$ & $2 \%$ \\
\hline$\sigma_{Q \mathrm{Br}}$ & $0.007 \mathrm{ml} \mathrm{min}^{-1}$ & $\begin{array}{l}10 \% \text { of } Q_{\mathrm{Br}}, \text { standard deviation of mean } \\
Q_{\mathrm{Br}} \text { for the entire experiment }\end{array}$ & $57 \%$ \\
\hline$\sigma_{m \mathrm{Br}}$ & $2.9-12.0 \mathrm{ppb}$ & $5 \%$ of $m_{\mathrm{Br}}$, analysis of standard solutions & $17 \%$ \\
\hline \multicolumn{4}{|l|}{$\underline{\text { FIA }}$} \\
\hline$\overline{\sigma_{m l i q}}($ gas) & $0.07-25.0 \mathrm{ppb}$ & $10 \%$ of $m l_{\text {liq }}$, analysis of standard solutions & $84 \%$ \\
\hline$\sigma_{Q s}($ gas $)$ & $0.017 \mathrm{ml} \mathrm{min}^{-1}$ & $\begin{array}{l}3 \% \text { of } Q_{s}, \text { standard deviation of mean } Q_{s} \\
\text { for the entire experiment }\end{array}$ & $10 \%$ \\
\hline$\sigma_{m \text { liq }}($ aerosol) & $0.15-7.9 \mathrm{ppb}$ & $10 \%$ of $m_{\text {liq }}$, analysis of standard solutions & $57 \%$ \\
\hline$\sigma_{Q s}($ aerosol $)$ & $0.041 \mathrm{ml} \mathrm{min}^{-1}$ & $\begin{array}{l}8 \% \text { of } Q_{s}, \text { standard deviation of mean } Q_{s} \\
\text { for the entire experiment }\end{array}$ & $37 \%$ \\
\hline$\sigma_{Q \text { air }}$ & $0.02-10.61 \mathrm{~min}^{-1}$ & $\begin{array}{l}\text { Standard deviation of mean } Q_{\text {air }} \text { for each } \\
\text { sampling interval }\end{array}$ & $6 \%$ \\
\hline
\end{tabular}

conditions during the wet season (1 to 14 November). Due to an instrument failure no samples were collected from 24 September to 7 October.

All results of our measurements of gas and aerosol species are presented as mixing ratios ( $p$ pb or nmol $\mathrm{mol}^{-1}$ ). All quantities were calculated for standard conditions of $298.15 \mathrm{~K}, 1000 \mathrm{hPa}$ and dry air, following the recommendations from Schwartz and Warneck (1995) and Mills et al. (1993).

\subsection{Estimation of measurement uncertainty}

The uncertainty of the measurements was estimated applying "Gaussian Error Propagation" to the relationship (5) which resulted in the following equation:

$\sigma_{m}=m \times$

$\sqrt[2]{\left(\frac{\sigma_{m_{\mathrm{liq}}}}{m_{\mathrm{liq}}}\right)^{2}+\left(\frac{\sigma_{m_{\mathrm{Br}(\mathrm{std})}}}{m_{\mathrm{Br}(\mathrm{std})}}\right)^{2}+\left(\frac{\sigma_{Q_{\mathrm{Br}}}}{Q_{\mathrm{Br}}}\right)^{2}+\left(\frac{\sigma_{m_{\mathrm{Br}}}}{m_{\mathrm{Br}}}\right)^{2}+\left(\frac{\sigma_{Q_{\mathrm{air}}}}{Q_{\mathrm{air}}}\right)^{2}}$,

where $\sigma_{m}$ is the estimated relative uncertainty of the ambient mixing ratio (ppb) and $\sigma_{x}$ are the standard deviations of the corresponding parameters (see Eq. 5). Equation (6) was also used to estimate uncertainties for ambient mixing ratios of $\mathrm{NH}_{3}$ and aerosol $\mathrm{NH}_{4}^{+}$, omitting the factors regarding $\mathrm{Br}^{-}$ standard addition and replacing $Q_{\mathrm{Br}}$ by $Q_{\mathrm{S}}$ and $\sigma_{\mathrm{Q}}$ by $\sigma_{\mathrm{Q}_{\mathrm{s}}}$.
Calculated total uncertainties $\sigma_{m}$ for all measurements and compounds usually ranged from $10-15 \%$, indicating a reliable and stable performance of the instrument. The standard deviations $\sigma_{x}$ contributing to the total measurement uncertainty $\sigma_{m}$ including their sources are listed in Table 2. For IC analyses, the contribution of $\sigma_{\mathrm{Q}_{\mathrm{Br}}}$ was highest $(57 \%$ of the total error, see Table 2) indicating that $\mathrm{Br}^{-}$addition to the sample by the peristaltic pump is the largest source of measurement error. For FIA analyses, the value of $\sigma_{m_{\text {liq }}}$ had the highest contribution to $\sigma_{m}$ (84\% and $57 \%$ for $\mathrm{NH}_{3}$ and $\mathrm{NH}_{4}^{+}$ analyses, respectively). Reasons for that may be an incomplete removal of the temperature dependence by Eq. (4), and also the temperature influence on the equilibrium constant of $\mathrm{NH}_{4} \mathrm{OH}$ and the permeation of $\mathrm{NH}_{3}$ through the membrane.

\subsection{Limit of detection (LOD)}

The accurate characterization and determination of the limit of detection is crucial for measurements in regions like the Amazon Basin since concentration levels can be extremely low during the wet season. The limit of detection ( $\mathrm{LOD}=3 \sigma$; $\sigma=$ standard deviation of the background signal) was determined for actual field conditions for every individual data point and each compound. For anionic species analyzed with IC, the background noise $(3 \sigma)$ was calculated from the variation of the baseline at the beginning and the end of each chromatogram comprising $11 \%(n=542)$ of the total chromatogram data points. The limit of detection $(\mathrm{LOD}=3 \sigma)$ for 
(a)

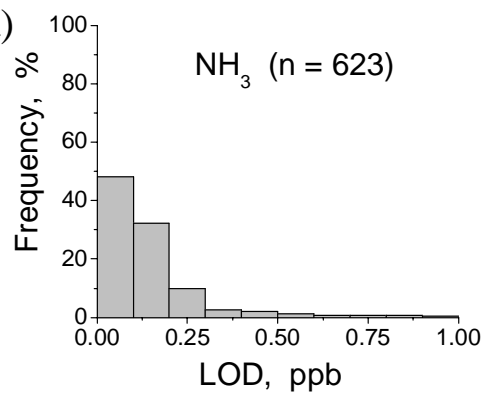

(b)

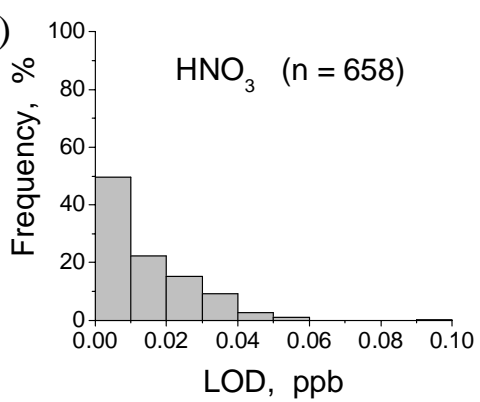

(c)

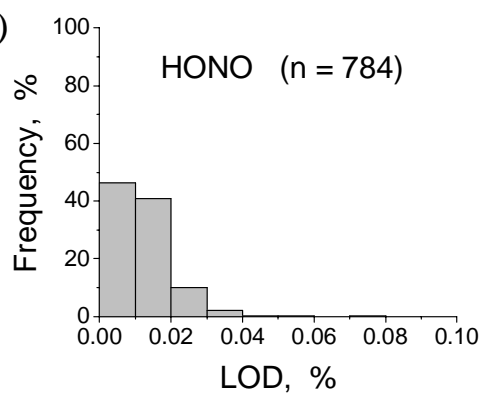

(d)

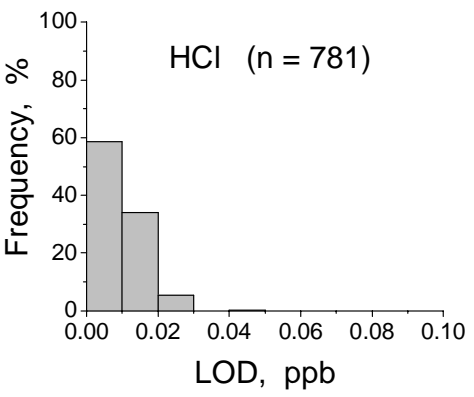

(e)

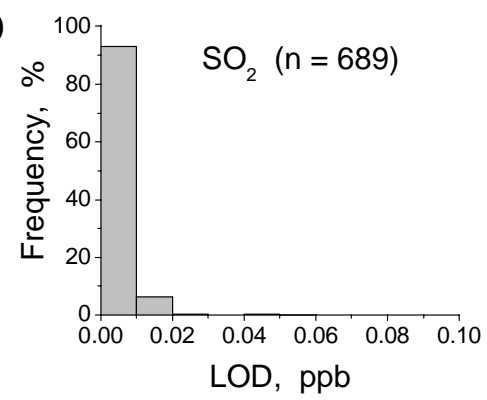

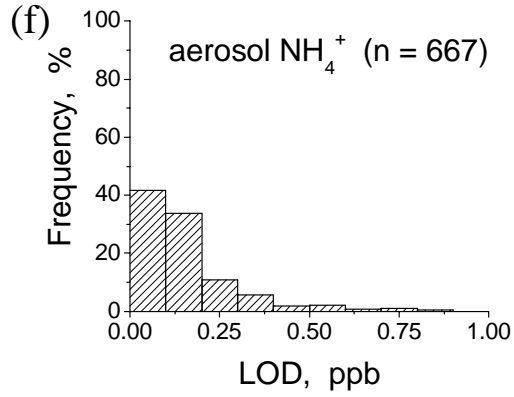

(g) 100

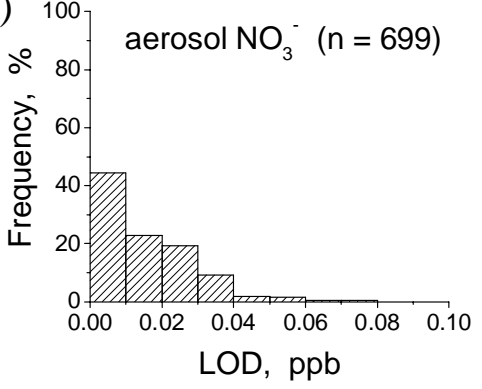

(h) $\left.\stackrel{100}{\circ}{ }_{80}^{100}\right]$ aerosol $\mathrm{NO}_{2}^{-}(\mathrm{n}=631)$

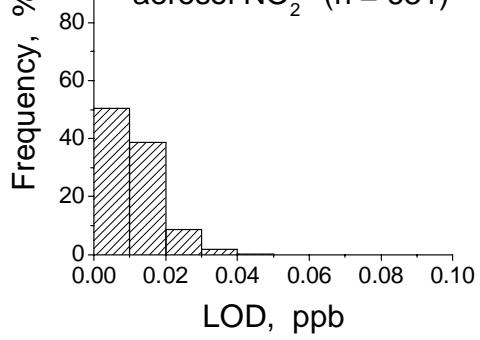

(i)

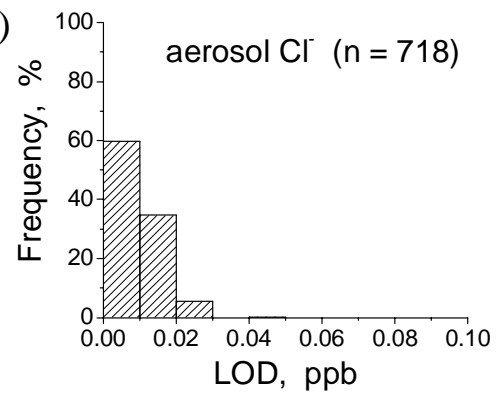

(j)

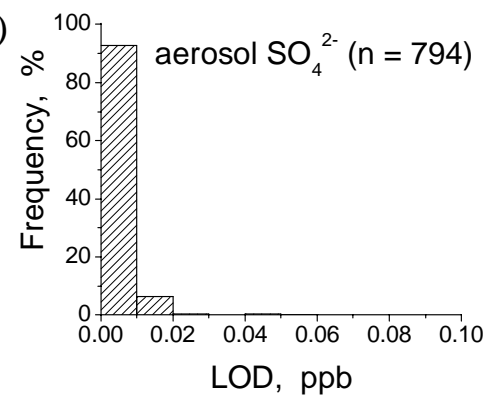

Fig. 3. (a-j). Limit of detection (LOD) frequency distributions distributions (given as atmospheric mixing ratios) of gaseous (a-e) and aerosol ( $\mathbf{f}-\mathbf{j})$ species measured at FNS during SMOCC 2002 ( $n=$ total number of values). 
the FIA analyses was determined analogously by background noise calculation before and after the $\mathrm{NH}_{4}^{+}$-peak, also comprising $11 \%(n=111)$ of the total measurements for each run. Frequency distributions of the LOD (given as atmospheric mixing ratios) for each compound during the entire field experiment are shown in histograms (Fig. 3). The determined median LOD values were $0.102 \mathrm{ppb}$ for $\mathrm{NH}_{3}, 0.011 \mathrm{ppb}$ for $\mathrm{HNO}_{3}, 0.012 \mathrm{ppb}$ for $\mathrm{HONO}, 0.008 \mathrm{ppb}$ for $\mathrm{HCl}, 0.004 \mathrm{ppb}$ for $\mathrm{SO}_{2}, 0.118 \mathrm{ppb}$ for aerosol $\mathrm{NH}_{4}^{+}, 0.015 \mathrm{ppb}$ for $\mathrm{NO}_{3}^{-}$, $0.009 \mathrm{ppb}$ for $\mathrm{NO}_{2}^{-}, 0.008 \mathrm{ppb}$ for $\mathrm{Cl}^{-}$and $0.004 \mathrm{ppb}$ for $\mathrm{SO}_{4}^{2-}$. Higher LOD values (see Fig. 3), were a result of unstable and noisy baselines caused by insufficient purity of the water, which was used as matrix for the solutions applied during analyses. The LOD values obtained for FIA were about an order of magnitude higher than for IC, because of the influence of temperature on detection procedures.

\subsection{Seasonal variation of mixing ratios}

Measurements of 10 different compounds were performed during the field experiment which resulted in $\sim 7000$ data points of ambient mixing ratios. The proportion of rejected data points below the LOD was $\leq 20 \%$ for all compounds, except for $\mathrm{NH}_{3}$ and $\mathrm{HNO}_{3}$ (25\%) and for aerosol $\mathrm{NO}_{2}^{-}(40 \%)$.

Statistical illustrations of the seasonal pattern of mixing ratios are shown in Fig. 4 for gaseous compounds and in Fig. 5 for aerosol species. A substantial decline of mixing ratio levels from dry season, through transition period to wet season was observed for all measured compounds. Gaseous $\mathrm{NH}_{3}$ was abundant at mixing ratios an order of magnitude higher than acidic trace gases, and maxima reached 8 ppb under burning conditions. Correspondingly, aerosol $\mathrm{NH}_{4}^{+}$was also found to be at least 4 to 10 times higher than anionic aerosol species. Values of $\mathrm{NH}_{3}$ and aerosol $\mathrm{NH}_{4}^{+}$declined by a factor of 2-3 from dry to wet season, suggesting that biomass burning is a strong source of these species. Also, $\mathrm{NH}_{3}$ emissions from cattle waste contributed to the observed levels. The amount of $\mathrm{NH}_{3}$ present during the wet season $(\sim 0.5 \mathrm{ppb}$, see Fig. 4$)$, when biomass burning activity was nearly zero, is expected to be entirely attributed to biogenic emissions from vegetation (grass) or cattle manure.

All acidic trace gases showed mixing ratios within the same order of magnitude (0.01-0.9 ppb) and decreased by more than a factor of 2 to the wet season. $\mathrm{SO}_{2}$ showed the lowest values (median $<0.1 \mathrm{ppb}$ ) and the least seasonal variation, suggesting that biomass burning is not a major source of this compound in this region. Mixing ratios of aerosol anions were highest during the biomass burning season. Unexpectedly, aerosol $\mathrm{NO}_{3}^{-}$(max $\sim 1.25 \mathrm{ppb}$ ) was most abundant, followed by aerosol $\mathrm{SO}_{4}^{2-}$ (max $\left.\sim 0.6 \mathrm{ppb}\right)$. Aerosol $\mathrm{NO}_{3}^{-}$dominated over $\mathrm{SO}_{4}^{2-}$ under biomass burning conditions and showed the strongest decrease to the wet season (factor $\sim 4$ ). $\mathrm{Cl}^{-}$and $\mathrm{NO}_{2}^{-}$contributed only very little to the aerosol inorganic composition and seasonal variations were smaller. Aerosol $\mathrm{NH}_{4}^{+}$in most cases exceeded the sum of $\mathrm{NO}_{3}^{-}, \mathrm{Cl}^{-}$and $\mathrm{SO}_{4}^{2-}$ equivalents. Consequently, other ions that were not measured by the WAD/SJAC system (e.g. dissociated organic acids, $\mathrm{K}^{+}, \mathrm{Ca}^{2+}$ ) may play an important role for the aerosol ion balance at FNS. This matter will be addressed in full detail in a subsequent paper (Trebs et al., to be submitted, $2004{ }^{1}$ ).

When widespread biomass burning occurred, $\mathrm{NH}_{3}$ mixing ratios at this Brazilian rural pasture site were similar to values observed with the WAD/SJAC at an urban location (EPA Atlanta Supersite, 1999; Zhang et al., 2002 and references therein). Nevertheless, $\mathrm{HNO}_{3}$ and $\mathrm{HONO}$ mixing ratios under burning conditions in the Amazon Basin were about five times lower than measured at the Atlanta Supersite (see Genfa et al., 2003). Aerosol $\mathrm{NO}_{3}^{-}$measured with the SJAC system in Atlanta compared relatively well to the values observed in our study (see Weber et al., 2003). However, $\mathrm{NH}_{4}^{+}$was about five times and $\mathrm{SO}_{4}^{2-}$ an order of magnitude larger at the urban site (Solomon et al., 2003; Weber et al., 2003). These results show that pollution in urban areas can be more severe than during biomass burning in the Amazon Basin.

\subsection{Diel variations of trace gases}

\subsection{1 $\mathrm{NH}_{3}$ and $\mathrm{HNO}_{3}$}

Figure 6 shows diel cycles for $\mathrm{NH}_{3}$ and $\mathrm{HNO}_{3}$ from 17 to 20 September 2002 (burning season), exhibiting a pronounced diel variation. $\mathrm{NH}_{3}$ was relatively low from 14:00 to $05: 00$ (1 to $3 \mathrm{ppb}$ ), with one exception in the night from the 18 to 19 September. Usually, elevated $\mathrm{NH}_{3}$ mixing ratios occurred from 07:00 to 10:00 with sharp peaks between 08:00 and 09:00. However, these peaks did not correlate with wind speed or wind direction (not shown here). Presumably, this behavior is due to the increase of air temperature after sunrise causing re-evaporation of deposited $\mathrm{NH}_{3}$ from wet surfaces (grass leaves). This is also discussed in more detail in Trebs et al. (2004b).

The diel variation observed for $\mathrm{HNO}_{3}$ usually featured low values during the night from 18:00 to $06: 00(<0.2 \mathrm{ppb})$ and high values at daytime reaching maxima around midday $(0.4$ to $0.6 \mathrm{ppb})$. Such diel cycles are typical for this compound and resemble those found in several other studies (e.g. Tanner et al., 1989; Meixner, 1994; Mehlmann and Warneck, 1995; Fehsenfeld et al., 1998; Lefer et al., 1999; Furutani and Akimoto, 2002; Huang et al., 2002; Genfa et al., 2003). The main reasons for this behavior are: (a) intensive turbulent mixing from the free troposphere into the boundary layer dur-

\footnotetext{
${ }^{1}$ Trebs, I., Metzger, S., Meixner, F. X., Helas, G., Andreae, M. O., Moura, M. A. L., Da Silva, R. J., Slanina, J., Rudich, Y., Falkovich, A., and Artaxo, P.: The $\mathrm{NH}_{4}^{+}-\mathrm{NO}_{3}^{-}-\mathrm{Cl}^{-}-\mathrm{SO}_{4}^{2-}-\mathrm{H}_{2} O$ system and its gas phase precursors at a rural site in the Amazon Basin: How relevant are crustal species and soluble organic compounds?, to be submitted to J. Geophys. Res.-Atmos., 2004b.
} 


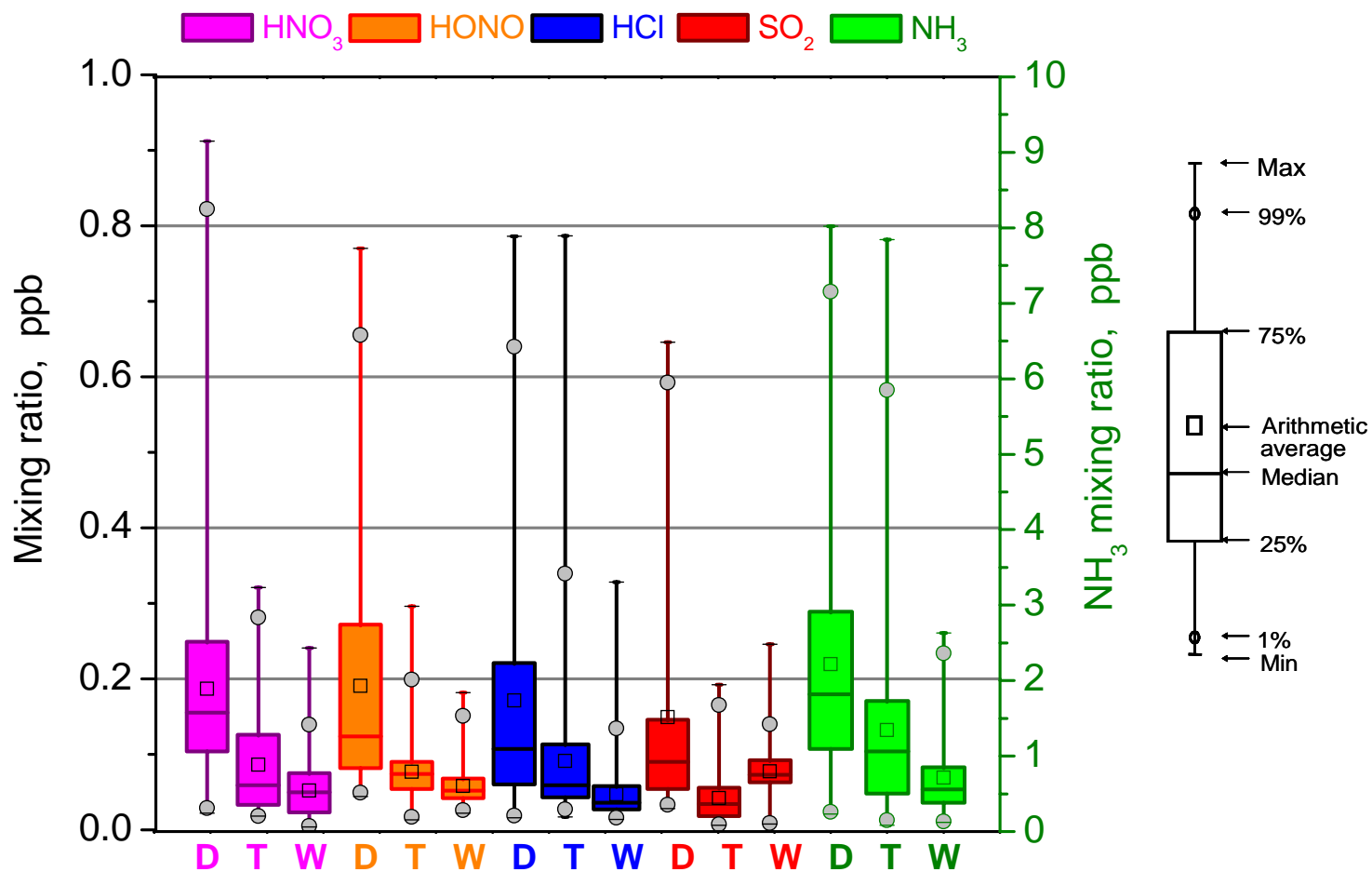

Fig. 4. Box-and-whisker plots showing seasonal mixing ratio variations of gaseous compounds during dry season (D), transition period (T) and wet season (W) at FNS during SMOCC 2002.

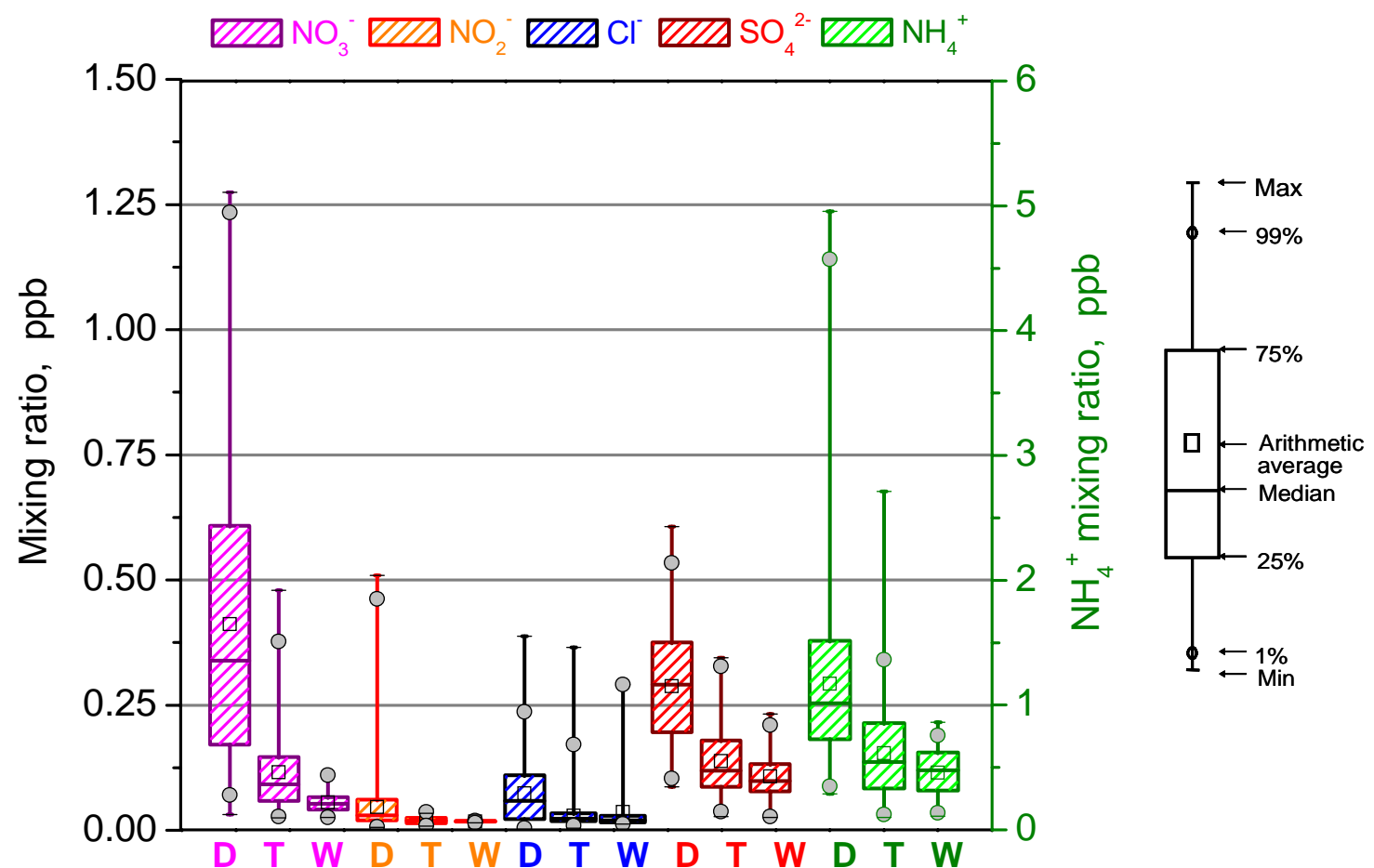

Fig. 5. Box-and-whisker plots showing seasonal mixing ratio variations of aerosol species during dry season (D), transition period (T) and wet season (W) at FNS during SMOCC 2002. Aerosol measurements of bulk and fine fraction $\left(\mathrm{D}_{p}<2.5 \mu \mathrm{m}\right)$ where included. 


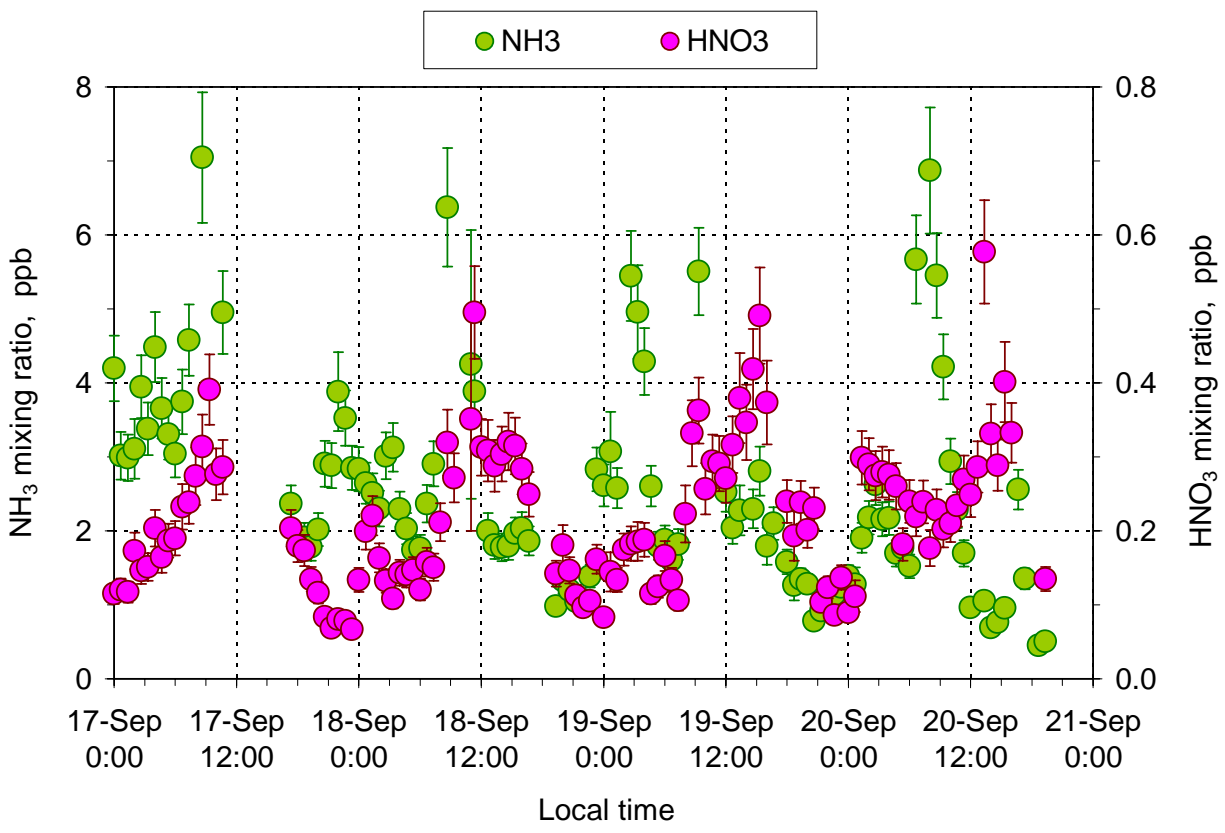

Fig. 6. Diel variations of $\mathrm{NH}_{3}$ and $\mathrm{HNO}_{3}$ from 17 to 20 September (biomass burning season) at FNS during SMOCC 2002. Error bars indicate measurement uncertainty for each data point.

ing daytime, (b) deposition processes at night promoted by a stable thermal stratification of the nocturnal surface layer (limiting $\mathrm{HNO}_{3}$ supply from residual layer), (c) higher temperature and lower relative humidity during daytime which enables evaporation of $\mathrm{HNO}_{3}$ from the aerosol phase, and (d) daytime photochemistry (reaction of $\mathrm{NO}_{2}$ with $\mathrm{OH}$ radical).

\subsubsection{HONO}

Spindler et al. (2003) have proposed a correction algorithm for artifact aqueous formation of $\mathrm{HONO}$ from dissolved $\mathrm{NO}_{2}$ and $\mathrm{SO}_{2}$ at wetted denuder walls. This has not been considered in our study for the following reasons: (a) artifact HONO formation is only significant for alkaline aqueous solutions, whereas the $\mathrm{pH}$ of the absorption solution in our study was nearly neutral, (b) the observed $\mathrm{SO}_{2}$ mixing ratios were at least 10 times lower (mostly $<0.3$ ppb, see Fig. 4) than those relevant for artifact HONO formation according to Spindler et al. (2003), and (c) since the absorber liquid was continuously pumped through the denuder, the contact time of the gas with the liquid was limited to 2 or 3 minutes.

Figure 7 shows diel patterns of HONO measured from 17 to 20 September 2002 (biomass burning season) and from 17 to 20 October 2002 (transition period). In the burning season, HONO featured a pronounced diel cycle with higher values at night, reaching maxima just after 00:00 (0.4 to $0.6 \mathrm{ppb}$ ). Heterogeneous reaction of $\mathrm{NO}_{2}$ with surface water as reported recently by Kleffmann et al. (2003) may be regarded as a HONO source, especially for nighttime HONO accumulation at high relative humidities at the site. During the day, HONO levels were low, varying between 0.05 and
$0.1 \mathrm{ppb}$. Similar HONO diel characteristics were observed in other studies (e.g. Perner and Platt, 1979; Appel et al., 1990; Harrison et al., 1996; Huang et al., 2002; Stutz et al., 2002; Alicke et al., 2003). Rapid photolysis during sunshine leads to a decline in HONO mixing ratios (Harrison et al., 1996). Moreover, our measurements in the Amazon Basin may be additional evidence for a continuous HONO source since a complete depletion at daytime did not occur.

Diel patterns observed one month later (transition period, see Fig. 7) show distinctive differences to those observed during the biomass burning season. HONO levels were identical in daylight and during nighttime resembling those measured in daylight under biomass burning conditions. Since $\mathrm{NO}_{2}$ is considered as the main reactant for heterogeneous HONO formation, obviously a declining $\mathrm{NO}_{2}$ abundance under cleaner conditions will diminish HONO accumulation at night.

\subsection{3 $\mathrm{HCl}$ and $\mathrm{SO}_{2}$}

Nighttime values of $\mathrm{HCl}$ and $\mathrm{SO}_{2}$ (Fig. 8) were very low in the burning season $(\sim 0.05$ to $0.1 \mathrm{ppb}$ ) while during daytime higher mixing ratios were found, with $\mathrm{HCl}$ exceeding $\mathrm{SO}_{2}$ levels by a factor of two or three. The marked diel pattern of $\mathrm{HCl}$ has a maximum in the early to mid afternoon, which is generally coincident with the period of maximum concentration of $\mathrm{HNO}_{3}$, in agreement with several previous investigations (Graedel and Keene, 1995 and references therein). While $\mathrm{HCl}$ is known to be emitted directly by biomass fires, accounting for a large fraction of the total emitted chlorine (Andreae et al., 1996), the observed $\mathrm{SO}_{2}$ mixing ratios may 


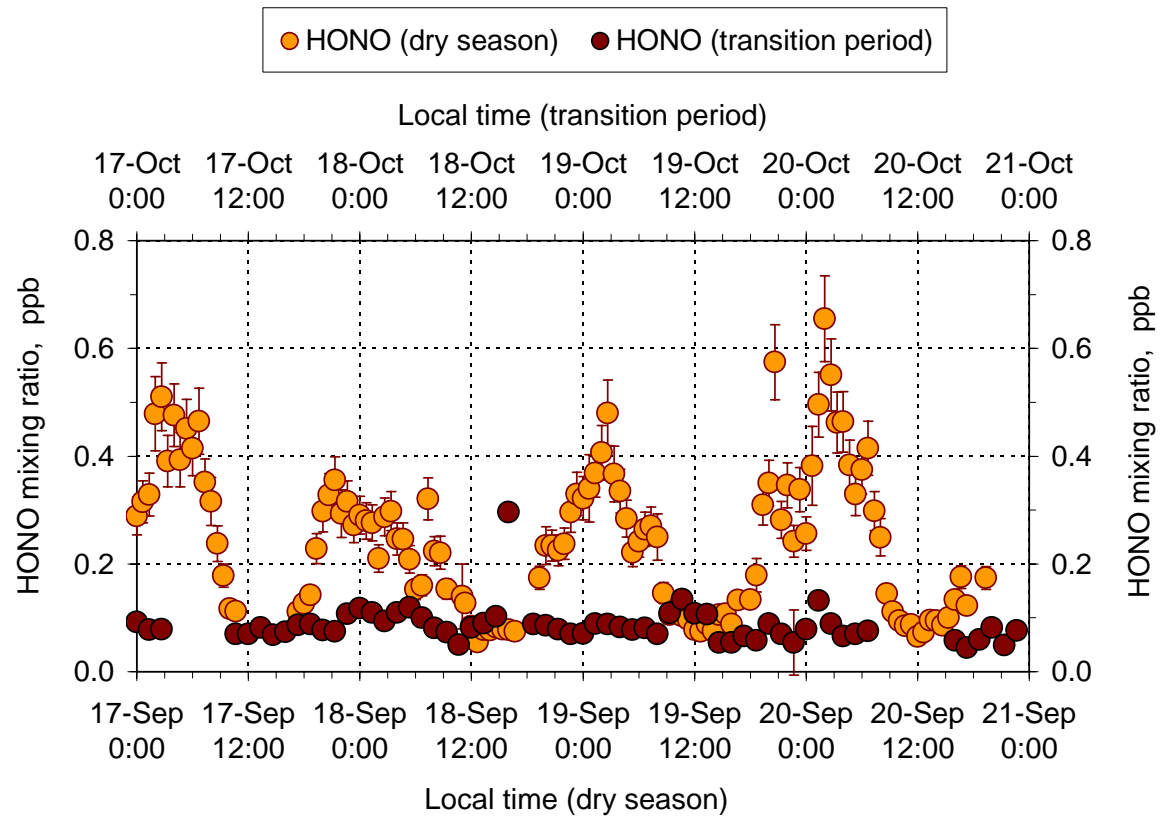

Fig. 7. Diel variations of HONO from 17 to 20 September (biomass burning season) and from 17 to 20 October (transition period) at FNS during SMOCC 2002. Error bars indicate measurement uncertainty for each data point.

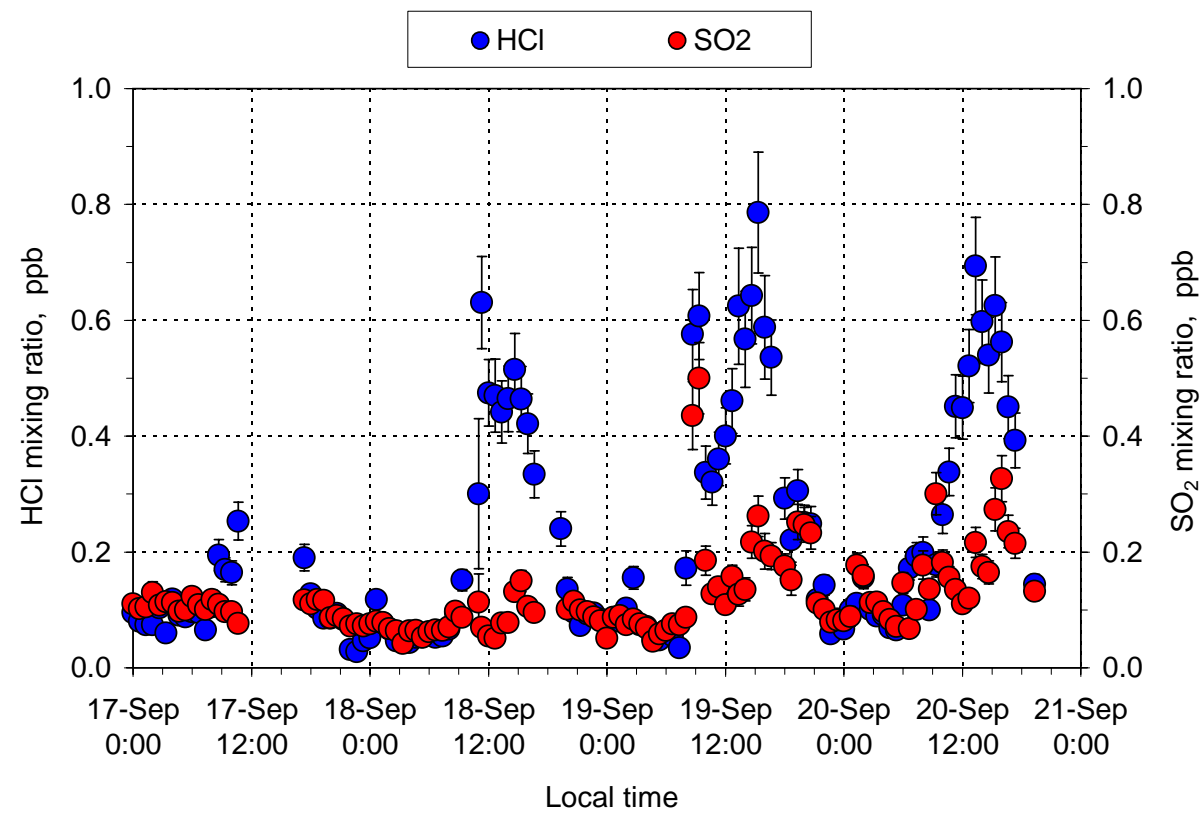

Fig. 8. Diel variations of $\mathrm{HCl}$ and $\mathrm{SO}_{2}$ from 17 to 20 September (biomass burning season) at FNS during SMOCC 2002. Error bars indicate measurement uncertainty for each data point.

have been largely caused by burning of charcoal and refuse nearby the site (Ouro Preto d'Oeste). Apparently, turbulent mixing in an expanding boundary layer during daytime and a stable thermal stratification at night (deposition of acidic gases on wet surfaces) have caused diel fluctuations as shown in Fig. 8.

\subsection{Diel variations of aerosol species}

\subsubsection{Aerosol $\mathrm{NH}_{4}^{+}, \mathrm{NO}_{3}^{-}$and $\mathrm{SO}_{4}^{2-}$}

Observed diel variations for aerosol $\mathrm{NH}_{4}^{+}, \mathrm{NO}_{3}^{-}$and $\mathrm{SO}_{4}^{2-}$ (fine fraction, $\mathrm{D}_{p} \leq 2.5 \mu \mathrm{m}$ ) from 17 to 20 September 2002 are plotted in Fig. 9a. As for corresponding gaseous species, pronounced diel patterns were found for $\mathrm{NH}_{4}^{+}$and $\mathrm{NO}_{3}^{-}$. 


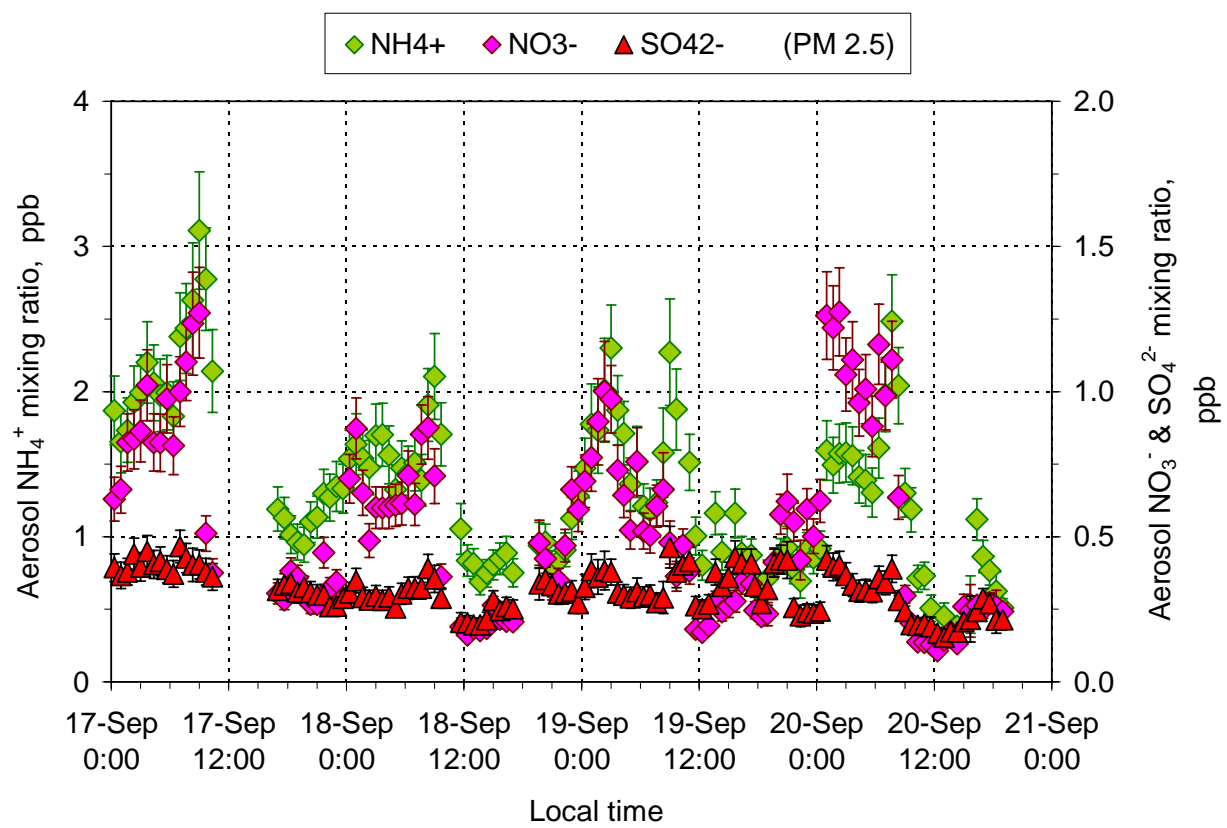

Fig. 9a. Diel variations of aerosol $\mathrm{NH}_{4}^{+}, \mathrm{NO}_{3}^{-}$and $\mathrm{SO}_{4}^{2-}$ (fine fraction, $\mathrm{D}_{p} \leq 2.5 \mu \mathrm{m}$ ) from 17 to 20 September (biomass burning season) at FNS during SMOCC 2002. Error bars indicate measurement uncertainty for each data point.

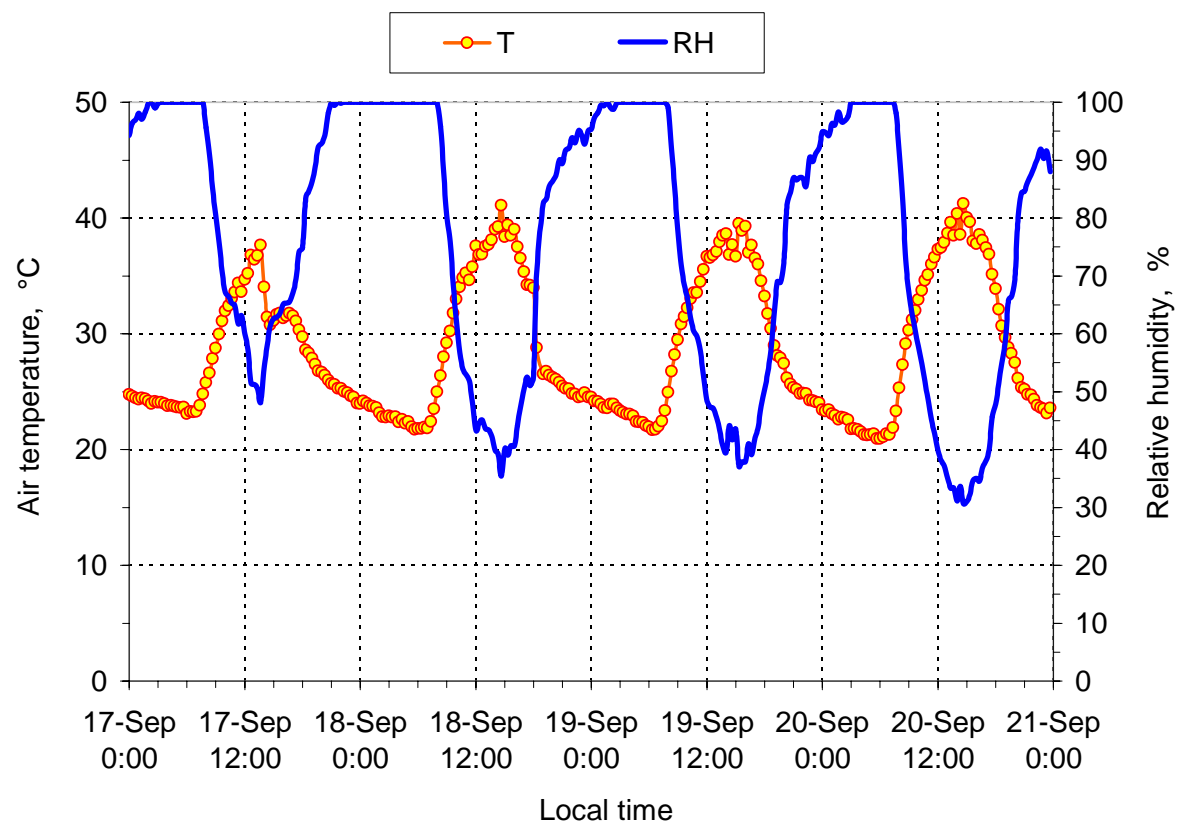

Fig. 9b. Diel variations of air temperature and relative humidity measured in the polyethylene conduit from 17 to 20 September (biomass burning season) at FNS during SMOCC 2002.

Obviously, $\mathrm{NH}_{4}^{+}$was strongly influenced by its gas phase precursor $\mathrm{NH}_{3}$, peaking between 08:00 and 09:00 in the morning and revealing much higher mixing ratios than the anionic aerosol species. Possible evaporation of $\mathrm{NH}_{3}$ from wet surfaces at sunrise, when relative humidities were still high (see Fig. 9b and Sect. 4.4.1) might have caused a significant fraction of gaseous $\mathrm{NH}_{3}$ to dissolve in still deli- quescent aerosols, therefore enhancing aerosol $\mathrm{NH}_{4}^{+}$. Generally, $\mathrm{NH}_{4}^{+}$and $\mathrm{NO}_{3}^{-}$began to increase at $\sim 22: 00$ and remained high during the night, while values found during daytime were usually two or three times lower (see Fig. 9a). Consequently, aerosol $\mathrm{NO}_{3}^{-}$showed a strong anti-correlation to $\mathrm{HNO}_{3}$. The equilibrium assumption between $\mathrm{NH}_{4} \mathrm{NO}_{3}$ and its gas phase precursors, strongly affected by relative 


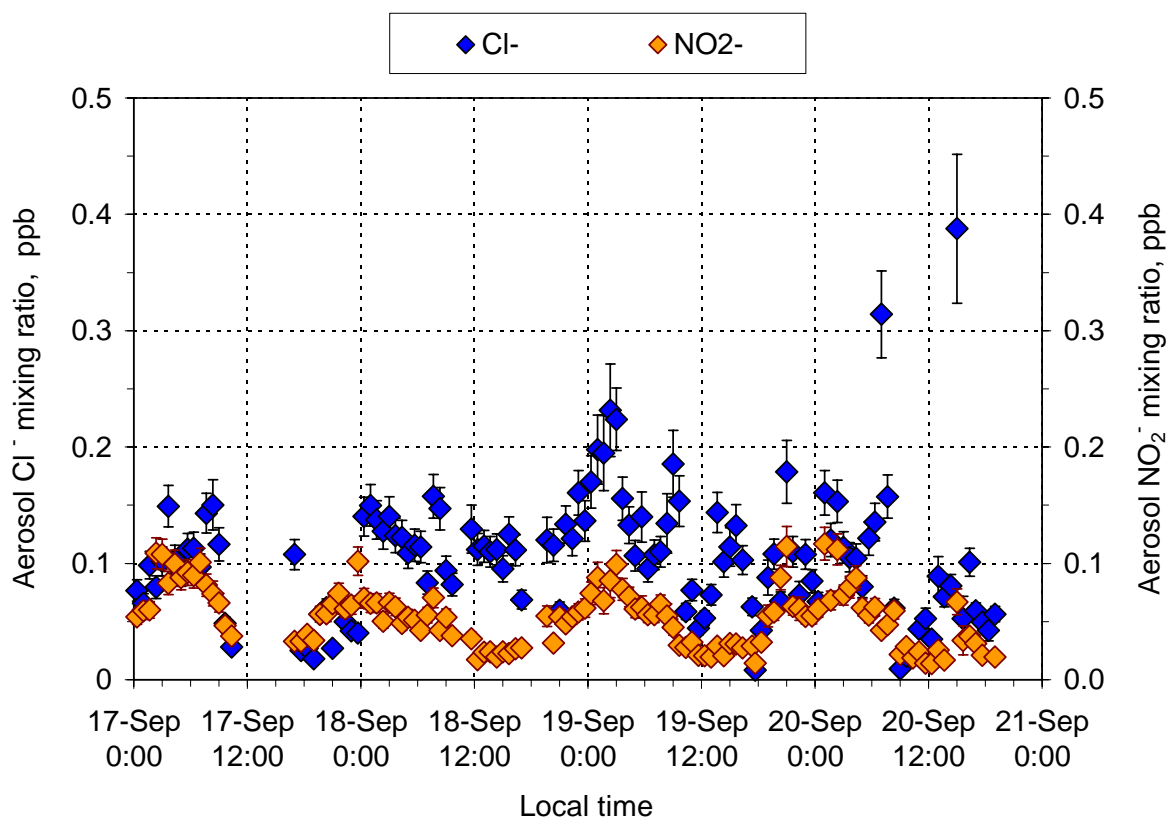

Fig. 10. Diel variations of aerosol $\mathrm{Cl}^{-}$and $\mathrm{NO}_{2}^{-}$(fine fraction, $\mathrm{D}_{p} \leq 2.5 \mu \mathrm{m}$ ) from 17 to 20 September (biomass burning season) at FNS during SMOCC 2002. Error bars indicate measurement uncertainty for each data point.

humidity and temperature, is expected to influence the measured gas and aerosol mixing ratios. High relative humidities and lower temperatures at night (Fig. 9b) should shift the equilibrium to the aerosol phase, causing the $\mathrm{NH}_{4} \mathrm{NO}_{3}$ content to increase and resulting in a simultaneous decrease of atmospheric gas phase constituents. At daytime, semivolatile species can evaporate from the aerosol phase, induced by lower relative humidities and higher temperatures (Fig. 9b), consequently raising the gas phase mixing ratios. The thermodynamic equilibrium assumption is discussed in Trebs et al. (2004b).

Time series of $\mathrm{SO}_{4}^{2-}$ did not show the same behavior. Mixing ratios were relatively stable throughout day and night, resembling those found for $\mathrm{NO}_{3}^{-}$during daytime. Considering the non-volatility of $\mathrm{SO}_{4}^{2-}$, relative humidity and temperature are not expected to influence the amount of $\mathrm{SO}_{4}^{2-}$ present in the sampled aerosol.

\subsubsection{Aerosol $\mathrm{Cl}^{-}$and $\mathrm{NO}_{2}^{-}$}

The diel cycles for aerosol $\mathrm{Cl}^{-}$and $\mathrm{NO}_{2}^{-}$(Fig. 10, fine fraction, $\left.\mathrm{D}_{p} \leq 2.5 \mu \mathrm{m}\right)$ during the burning season were less pronounced than for the other aerosol species. $\mathrm{NO}_{2}^{-}$is higher at night, which may be an indication of heterogeneous HONO formation on aerosol surfaces. $\mathrm{Cl}^{-}$mixing ratios featured less distinctive differences between day and night, suggesting that $\mathrm{Cl}^{-}$may either be attached to $\mathrm{NH}_{4}^{+}$or also to involatile cations such as $\mathrm{K}^{+}, \mathrm{Ca}^{2+}$ and $\mathrm{Na}^{+}$which are known to be present in fine and coarse mode biomass burning aerosols.
4.6 Diel characteristics of total ammonium, nitrate and chloride

The diel courses of aerosol species and their gaseous precursors presented in the previous sections are determined by (a) chemical production and loss, (b) horizontal and vertical transport within the planetary boundary layer, and (c) partitioning between gas and aerosol phase. Fig. 11a-c shows the temporal variation of total ammonium (aerosol $\mathrm{NH}_{4}^{+}+$ $\mathrm{NH}_{3}$ ), total nitrate (aerosol $\mathrm{NO}_{3}^{-}+\mathrm{HNO}_{3}$ ) and total chloride (aerosol $\mathrm{Cl}^{-}+\mathrm{HCl}$ ). For reasons of compactness and simplicity, diel variations are presented as medians with 0.25 and 0.75 percentiles of the individual data from 17 to 20 September 2002 (dry season, biomass burning). In these figures, the influence of gas/aerosol partitioning is removed; thus they may give some insight to which extent gas phase chemistry and transport have caused the observed diel patterns. Besides the sharp peaks occurring between 8:00 and 9:00, total ammonium (Fig. 11a) did not exhibit a distinct diel pattern. Lower mixing ratios after midday may be attributed to turbulent mixing and dilution of air masses on a local scale.

In contrast, total nitrate (Fig. 11b) was highest from midnight until 09:00. Apparently, this indicates accumulation of nitrate within the stable stratified nocturnal boundary layer, which was obviously dominated by the aerosol phase (see Fig. 9a). The decrease around noon may be attributed to the period of highest turbulent transport in the surface layer, which in turn might have caused a sizeable $\mathrm{HNO}_{3}$ deposition to the grass surface. This period is followed by a slight increase of total nitrate in mid-afternoon indicating the influence of photochemical $\mathrm{HNO}_{3}$ production. 


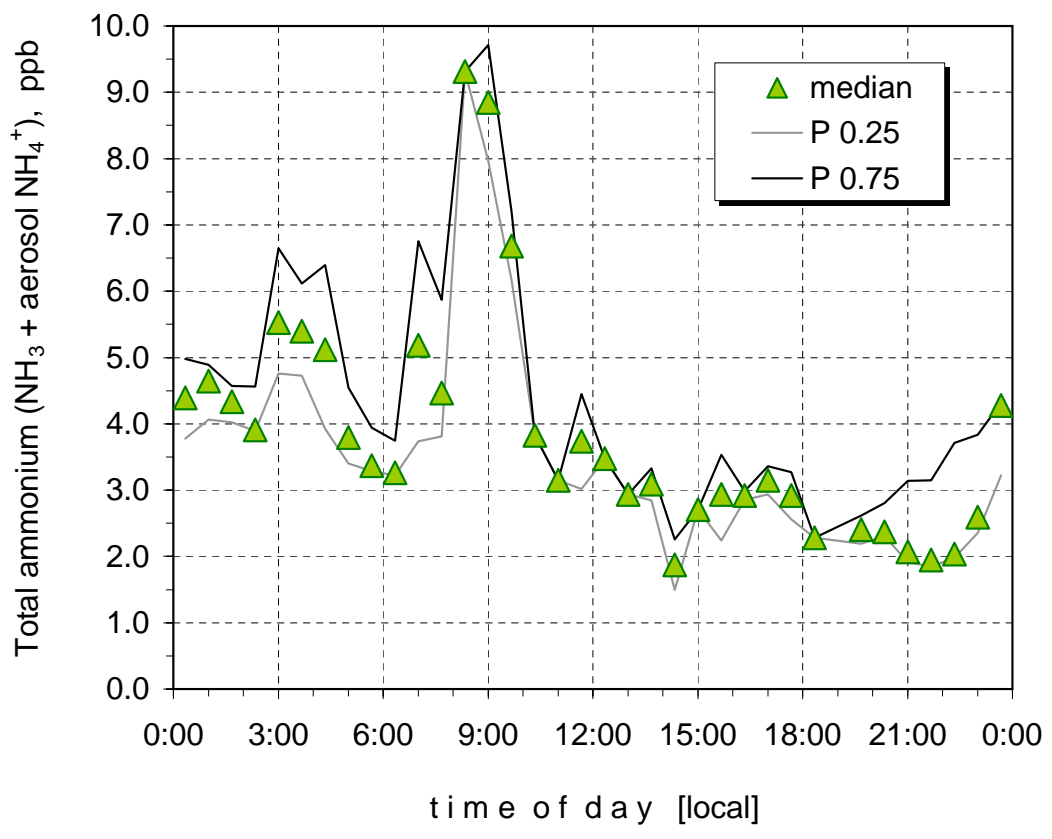

Fig. 11a. Median diel variation of total ammonium (aerosol $\mathrm{NH}_{4}^{+}+\mathrm{NH}_{3}$ ) covering a period during the biomass burning season (17-20 Sep.) at FNS during SMOCC 2002.

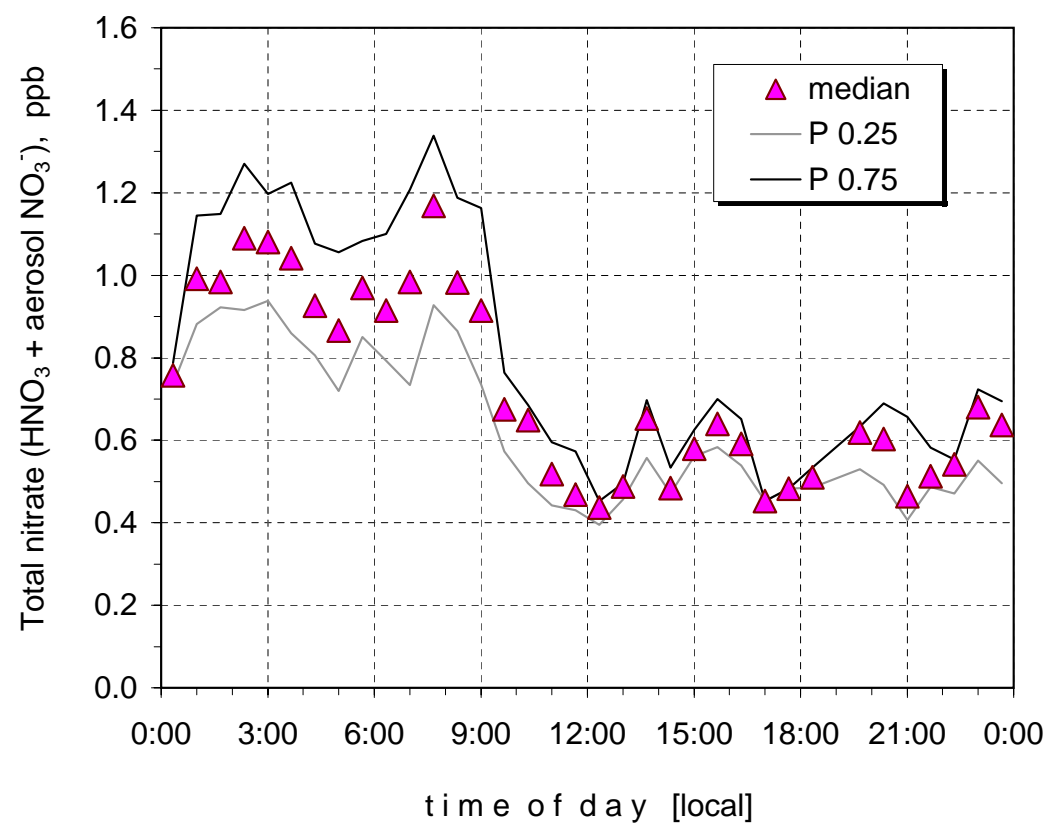

Fig. 11b. Median diel variation of total nitrate (aerosol $\mathrm{NO}_{3}^{-}+\mathrm{HNO}_{3}$ ) covering a period during the biomass burning season (17-20 Sep.) at FNS during SMOCC 2002.

The diel cycle of total chloride (Fig. 11c) was clearly dominated by gaseous $\mathrm{HCl}$ (cf. Fig. 8 and 10). Since most of the chloride was present in the gas phase, this diel variation was mainly determined by turbulent mixing at daytime and acid deposition to wet surfaces at night.

Atmos. Chem. Phys., 4, 967-987, 2004

\section{Conclusions}

We employed a WAD/SJAC coupled with IC and ammonium FIA for the continuous measurement of $\mathrm{NH}_{3}$, acidic trace gases $\left(\mathrm{HNO}_{3}, \mathrm{HONO}, \mathrm{HCl}\right.$ and $\left.\mathrm{SO}_{2}\right)$ and corresponding aerosol species $\left(\mathrm{NH}_{4}^{+}, \mathrm{NO}_{3}^{-}, \mathrm{NO}_{2}^{-}, \mathrm{Cl}^{-}\right.$and $\left.\mathrm{SO}_{4}^{2-}\right)$ at 


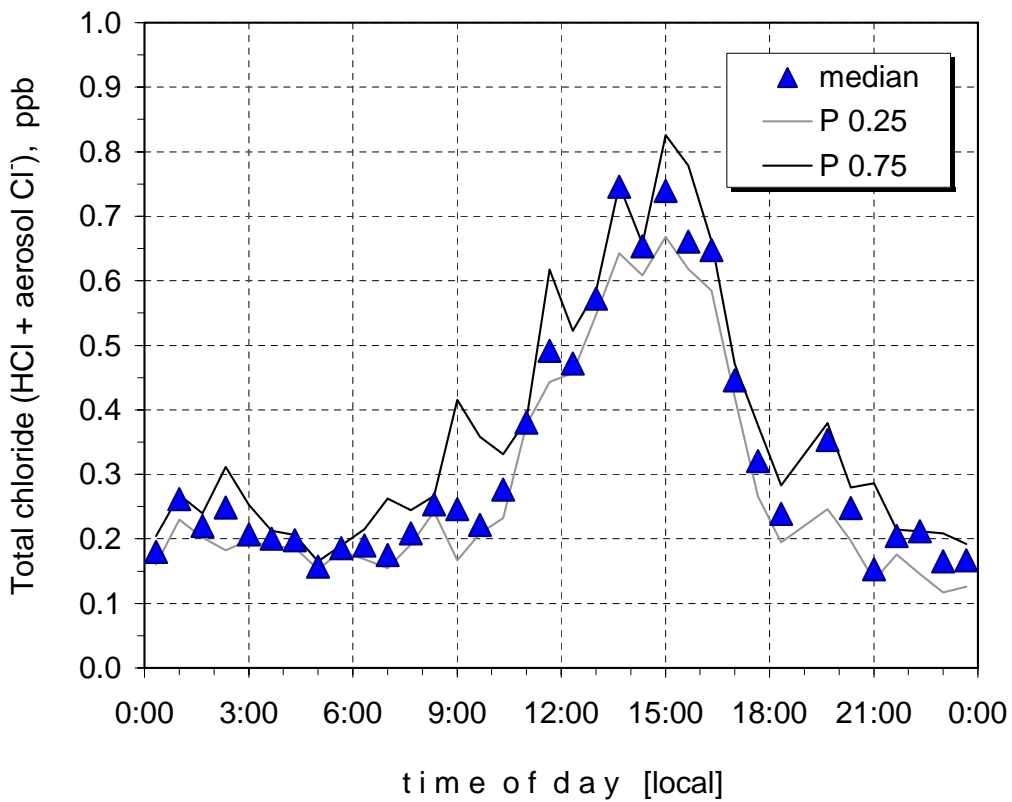

Fig. 11c. Median diel variation of total chloride (aerosol $\mathrm{Cl}^{-}+\mathrm{HCl}$ ) covering a period during the biomass burning season (17-20 Sep.) at FNS during SMOCC 2002.

a rural site in the Amazon Basin. A specially designed inlet system was applied for simultaneous sampling of gases and aerosols. Calculated inlet losses of aerosol species due to non-isokinetic sampling were below $3 \%\left(D_{p} \leq 2.5 \mu \mathrm{m}\right)$. $\mathrm{HNO}_{3}$ is known as a problematic compound regarding absorption on inlet surfaces. Theoretical wall losses for $\mathrm{HNO}_{3}$ were calculated to be $\leq 15 \%$, assuming an uptake coefficient of $\gamma_{\mathrm{HNO}_{3}}=0.5$ for the inlet surface.

Total measurement uncertainties of the mixing ratios in ambient air were usually below $15 \%$. The use of a peristaltic pump for the $\mathrm{Br}^{-}$standard addition to calibrate the IC was found to have the greatest contribution $(57 \%)$ to the total measurement error. In order to reduce the influence of this factor, peristaltic pumps should be replaced by other devices (e.g. syringe pumps), which are capable to supply more constant flows on a long-term scale.

The limit of detection $(\mathrm{LOD}=3 \sigma)$ was determined for each individual data point under actual field conditions. LOD median values remained below $0.015 \mathrm{ppb}$ for all acidic trace gases and aerosol anions (IC analyses) but were higher $(\leq 0.118 \mathrm{ppb})$ for $\mathrm{NH}_{3}$ and aerosol $\mathrm{NH}_{4}^{+}$(FIA analyses). Higher background noises during $\mathrm{NH}_{3}$ and aerosol $\mathrm{NH}_{4}^{+}$detection procedures were apparently caused by the temperature dependence of the FIA analyses, which should therefore be carried out under temperature controlled conditions in the future.

Widespread biomass burning in the Amazon Basin was found to be a strong source of $\mathrm{NH}_{3}$, present at mixing ratios about 3 times higher ( $\max \sim 8 \mathrm{ppb}$ ) than under clean conditions during the wet season. Also, levels of $\mathrm{HNO}_{3}, \mathrm{HONO}$ and $\mathrm{HCl}$ were considerably higher than during the wet sea- son (at least two times) but were an order of magnitude lower $(<1 \mathrm{ppb})$ than the $\mathrm{NH}_{3}$ mixing ratios. The enhancement of gaseous compounds during the burning season significantly increased the amount of water-soluble inorganic aerosol constituents. Aerosol $\mathrm{NH}_{4}^{+}$was found to be at least 4 to 10 times higher than anionic aerosol species but declined substantially from dry to wet season. Generally, aerosol $\mathrm{NO}_{3}^{-}$and $\mathrm{SO}_{4}^{2-}$ were the most abundant anions reaching maxima of $1.25 \mathrm{ppb}$ and $0.6 \mathrm{ppb}$, respectively. During the biomass burning season, aerosol $\mathrm{NO}_{3}^{-}$was the dominating anion and showed the strongest decrease to the wet season $(\sim 70 \%)$. Aerosol $\mathrm{NH}_{4}^{+}$ usually exceeded the sum of $\mathrm{NO}_{3}^{-}, \mathrm{Cl}^{-}$and $\mathrm{SO}_{4}^{2-}$ equivalents.

Additionally, N-containing gas and aerosol species exhibited pronounced diel variations, and both $\mathrm{HCl}$ and $\mathrm{SO}_{2}$ varied distinctively with maxima at daytime and minima during the night. Turbulent mixing at daytime is considered to have a major influence on the observed diel patterns, contributing to an increase of gaseous compounds at ground level. Deposition processes at night combined with high relative humidity and a stable thermal stratification of the nocturnal surface layer may cause a decline of trace gas mixing ratios (particularly $\mathrm{HNO}_{3}, \mathrm{HCl}$ and $\mathrm{SO}_{2}$ ) at nighttime. Moreover, our measurements indicate that the partitioning between $\mathrm{N}$-containing gas and corresponding aerosol constituents was dependent on relative humidity and air temperature, resulting in an enhancement of aerosol $\mathrm{NO}_{3}^{-}$and $\mathrm{NH}_{4}^{+}$at nighttime. Non-volatile aerosol $\mathrm{SO}_{4}^{2-}$ did not show strong diel fluctuations and remained stable throughout day and night. Diel courses of total ammonium, nitrate and chloride (gas + aerosol) emphasize the role of photochemical 
$\mathrm{HNO}_{3}$ production, vertical mixing as well as dry deposition of $\mathrm{HNO}_{3}$ (daytime) and $\mathrm{HCl}$ (particularly nighttime) to the grass surface.

HONO showed a typical diel pattern when biomass burning occurred, exhibiting higher mixing ratios at night and lower values during daylight. Besides heterogeneous formation from $\mathrm{NO}_{2}$ and surface water, our observations suggest a continuous HONO source since a complete depletion during sunlight hours did not occur.

A subsequent publication (Trebs et al., 2004b) provides more detailed insights into aerosol ion balances and gas/aerosol partitioning processes at the FNS site. Additionally, the diel behavior of the measured species in combination with meteorological conditions is addressed.

Acknowledgements. The authors gratefully acknowledge financial support by the European Commission (contract $\mathrm{N}^{\circ}$ EVK2-CT2001-00110 SMOCC) and by the Max Planck Society. We are grateful to P. Artaxo for the organization of the field experiment and his help in logistical issues. Also, the authors wish to thank P. Guyon, J. von Jouanne, and G. Helas for their support. Special thanks go to O. L. Mayol-Bracero, S. Gonzalez, L. Soto, A. Camargo, M. A. L. Moura and R. S. da Silva, Jr. for their help during the field measurements. Additionally, we would like to acknowledge three anonymous reviewers and S. Martin (editor) for their valuable comments and suggestions.

Edited by: S. Martin

\section{References}

Abbas, R. and Tanner, R. L.: Continuous Determination of Gaseous Ammonia in the Ambient Atmosphere Using Fluorescence Derivatization, Atmos. Environ., 15, 277-281, 1981.

Alicke, B., Geyer, A., Hofzumahaus, A., Holland, F., Konrad, S., Patz, H. W., Schafer, J., Stutz, J., Volz-Thomas, A., and Platt, U.: $\mathrm{OH}$ formation by HONO photolysis during the BERLIOZ experiment, J. Geophys. Res.-Atmos., 108, D4, 8247, doi:10.1029/2001JD000579, 2003.

Allegrini, I., Febo, A., Perrino, C., and Masia, P.: Measurement of Atmospheric Nitric-Acid in Gas-Phase and Nitrate in Particulate Matter by Means of Annular Denuders, Int. J. Environ. Anal. Chem., 54, 183-201, 1994.

Andreae, M. O., Artaxo, P., Brandao, C., Carswell, F. E., Ciccioli, P., da Costa, A. L., Culf, A. D., Esteves, J. L., Gash, J. H. C., Grace, J., Kabat, P., Lelieveld, J., Malhi, Y., Manzi, A. O., Meixner, F. X., Nobre, A. D., Nobre, C., Ruivo, M., Silva-Dias, M. A., Stefani, P., Valentini, R., von Jouanne, J., and Waterloo, M. J.: Biogeochemical cycling of carbon, water, energy, trace gases, and aerosols in Amazonia: The LBAEUSTACH experiments, J. Geophys. Res.-Atmos., 107, D20, 8066, doi:10.1029/2001JD000524, 2002.

Andreae, M. O., Atlas, E., Harris, G. W., Helas, G., deKock, A., Koppmann, R., Maenhaut, W., Mano, S., Pollock, W. H., Rudolph, J., Scharffe, D., Schebeske, G., and Welling, M.: Methyl halide emissions from savanna fires in southern Africa, J. Geophys. Res.-Atmos., 101, 23 603-23 613, 1996.
Appel, B. R.: Sampling of Selected Labile Atmospheric Pollutants, Adv. Chem. Ser., 1-40, 1993.

Appel, B. R., Povard, V., and Kothny, E. L.: Loss of Nitric-Acid within Inlet Devices Intended to Exclude Coarse Particles During Atmospheric Sampling, Atmos. Environ., 22, 2535-2540, 1988.

Appel, B. R. and Tokiwa, Y.: Atmospheric Particulate Nitrate Sampling Errors Due to Reactions with Particulate and Gaseous Strong Acids, Atmos. Environ., 15, 1087-1089, 1981.

Appel, B. R., Tokiwa, Y., and Haik, M.: Sampling of Nitrates in Ambient Air, Atmos. Environ., 15, 283-289, 1981.

Appel, B. R., Tokiwa, Y., Haik, M., and Kothny, E. L.: Artifact Particulate Sulfate and Nitrate Formation on Filter Media, Atmos. Environ., 18, 409-416, 1984.

Appel, B. R., Tokiwa, Y., Povard, V., and Kothny, E. L.: The Measurement of Atmospheric Hydrochloric-Acid in Southern California, Atmos. Environ. Part A - General Topics, 25, 525-527, 1991.

Appel, B. R., Wall, S. M., Tokiwa, Y., and Haik, M.: Simultaneous Nitric-Acid, Particulate Nitrate and Acidity Measurements in Ambient Air, Atmos. Environ., 14, 549-554, 1980.

Appel, B. R., Winer, A. M., Tokiwa, Y., and Biermann, H. W.: Comparison of Atmospheric Nitrous-Acid Measurements by Annular Denuder and Differential Optical-Absorption Systems, Atmos. Environ. Part A - General Topics, 24, 611-616, 1990.

Asman, W. A. H., Sutton, M. A., and Schjorring, J. K.: Ammonia: emission, atmospheric transport and deposition, New Phytol., 139, 27-48, 1998.

Aumont, B., Chervier, F., and Laval, S.: Contribution of HONO sources to the $\mathrm{NO}_{\mathrm{x}} / \mathrm{HO}_{\mathrm{x}} / \mathrm{O}_{3}$ chemistry in the polluted boundary layer, Atmos. Environ., 37, 487-498, 2003.

Boring, C. B., Poruthoor, S. K., and Dasgupta, P. K.: Wet effluent parallel plate diffusion denuder coupled capillary ion chromatograph for the determination of atmospheric trace gases, Talanta, 48, 675-684, 1999.

Braman, R. S., Shelley, T. J., and McClenny, W. A.: Tungstic Acid for Pre-Concentration and Determination of Gaseous and Particulate Ammonia and Nitric-Acid in Ambient Air, Anal. Chem., 54, 358-364, 1982.

Buhr, S. M., Buhr, M. P., Fehsenfeld, F. C., Holloway, J. S., Karst, U., Norton, R. B., Parrish, D. D., and Sievers, R. E.: Development of a Semicontinuous Method for the Measurement of Nitric-Acid Vapor and Particulate Nitrate and Sulfate, Atmos. Environ., 29, 2609-2624, 1995.

Cadle, S. H., Countess, R. J., and Kelly, N. A.: Nitric-Acid and Ammonia in Urban and Rural Locations, Atmos. Environ., 16, 2501-2506, 1982

Cheng, Y. H., and Tsai, C. J.: Evaporation loss of ammonium nitrate particles during filter sampling, J. Aerosol. Sci., 28, 1553-1567, 1997.

Cofer, W. R., Collins, V. G., and Talbot, R. W.: Improved Aqueous Scrubber for Collection of Soluble Atmospheric Trace Gases, Environ. Sci. Technol., 19, 557-560, 1985.

Danalatos, D. and Glavas, S.: Gas phase nitric acid, ammonia and related particulate matter at a Mediterranean coastal site, Patras, Greece, Atmos. Environ., 33, 3417-3425, 1999.

Dasgupta, P. K.: Automated Measurement of Atmospheric Trace Gases - Diffusion - Based Collection and Analysis, Adv. Chem. Ser., 41-90, 1993. 
Deandrade, J. B., Dearagao, N. M., and Araujo, F. R. J.: Nitric-Acid Air-Diffusion Coefficient - Experimental-Determination Using a Diffusion Cell, Int. J. Environ. Anal. Chem., 49, 103-109, 1992.

Dlugi, R.: Interaction of NOx and VOCs within vegetation, in: Photo-oxidants: Precursors and Products, edited by Borrell, P. M., Borrell, P., Cvitas, T., and Seiler, W., Proc. of EUROTRAC Symposium '92, Academic Publishing, The Hague, pp. 682-688, 1993.

Doyle, G. J., Tuazon, E. C., Graham, R. A., Mischke, T. M., Winer, A. M., and Pitts, J. N.: Simultaneous Concentrations of Ammonia and Nitric-Acid in a Polluted Atmosphere and Their Equilibrium Relationship to Particulate Ammonium-Nitrate, Environ. Sci. Technol., 13, 1416-1419, 1979.

Durham, J. L., Spiller, L. L., and Ellestad, T. G.: Nitric-Acid Nitrate Aerosol Measurements by a Diffusion Denuder - a Performance Evaluation, Atmos. Environ., 21, 589-598, 1987.

Durham, J. L. and Stockburger, L.: Nitric-Acid Air DiffusionCoefficient-Experimental Determination, Atmos. Environ., 20, 559-563, 1986.

Eatough, D. J., White, V. F., Hansen, L. D., Eatough, N. L., and Ellis, E. C.: Hydration of Nitric-Acid and Its Collection in the Atmosphere by Diffusion Denuders, Anal. Chem., 57, 743-748, 1985.

Erisman, J. W., Otjes, R., Hensen, A., Jongejan, P., van den Bulk, P., Khlystov, A., Mols, H., and Slanina, J.: Instrument development and application in studies and monitoring of ambient ammonia, Atmos. Environ., 35, 1913-1922, 2001.

Febo, A., Perrino, C., and Allegrini, I.: Measurement of nitrous acid in Milan, Italy, by DOAS and diffusion denuders, Atmos. Environ., 30, 3599-3609, 1996.

Fehsenfeld, F. C., Huey, L. G., Sueper, D. T., Norton, R. B., Williams, E. J., Eisele, F. L., Mauldin, R. L., and Tanner, D. J.: Ground-based intercomparison of nitric acid measurement techniques, J. Geophys. Res.-Atmos., 103, 3343-3353, 1998.

Furutani, H. and Akimoto, H.: Development and characterization of a fast measurement system for gas-phase nitric acid with a chemical ionization mass spectrometer in the marine boundary layer, J. Geophys. Res.-Atmos., 107, D1-D2, doi:10.1029/2000JD000269, 2002.

Galasyn, J. F., Tschudy, K. L., and Huebert, B. J.: Seasonal and Diurnal Variability of Nitric-Acid Vapor and Ionic Aerosol Species in the Remote Free Troposphere at Mauna-Loa, Hawaii, J. Geophys. Res.-Atmos., 92, 3105-3113, 1987.

Gard, E., Mayer, J. E., Morrical, B. D., Dienes, T., Fergenson, D. P., and Prather, K. A.: Real-time analysis of individual atmospheric aerosol particles: Design and performance of a portable ATOFMS, Anal. Chem., 69, 4083-4091, 1997.

Genfa, Z. F., Slanina, S., Boring, C. B., Jongejan, P. A. C., and Dasgupta, P. K.: Continuous wet denuder measurements of atmospheric nitric and nitrous acids during the 1999 Atlanta Supersite, Atmos. Environ., 37, 1351-1364, 2003.

Gormley, P. G. and Kennedy, M.: Diffusion from a stream flowing trough a cylindrical tube, Proceedings of the Royal Irish Academy, 52A, 163-169, 1949.

Graedel, T. E. and Keene, W. C.: Tropospheric Budget of Reactive Chlorine, Glob. Biogeochem. Cycle, 9, 47-77, 1995.

Hanke, M., Umann, B., Uecker, J., Arnold, F., and Bunz, H.: Atmospheric measurements of gas-phase $\mathrm{HNO}_{3}$ and $\mathrm{SO}_{2}$ using chemical ionization mass spectrometry during the MINATROC field campaign 2000 on Monte Cimone, Atmos. Chem. Phys., 3, $417-$ 436, 2003.

Harrison, R. M. and Kitto, A. M. N.: Evidence for a Surface Source of Atmospheric Nitrous-Acid, Atmos. Environ., 28, 1089-1094, 1994.

Harrison, R. M., Peak, J. D., and Collins, G. M.: Tropospheric cycle of nitrous acid, J. Geophys. Res.-Atmos., 101, 14 429-14439, 1996.

Heland, J., Kleffmann, J., Kurtenbach, R., and Wiesen, P.: A new instrument to measure gaseous nitrous acid (HONO) in the atmosphere, Environ. Sci. Technol., 35, 3207-3212, 2001.

Hering, S. V., Lawson, D. R., Allegrini, I., Febo, A., Perrino, C., Possanzini, M., Sickles, J. E., Anlauf, K. G., Wiebe, A., Appel, B. R., John, W., Ondo, J., Wall, S., Braman, R. S., Sutton, R., Cass, G. R., Solomon, P. A., Eatough, D. J., Eatough, N. L., Ellis, E. C., Grosjean, D., Hicks, B. B., Womack, J. D., Horrocks, J., Knapp, K. T., Ellestad, T. G., Paur, R. J., Mitchell, W. J., Pleasant, M., Peake, E., Maclean, A., Pierson, W. R., Brachaczek, W., Schiff, H. I., Mackay, G. I., Spicer, C. W., Stedman, D. H., Winer, A. M., Biermann, H. W., and Tuazon, E. C.: The Nitric-Acid Shootout - Field Comparison of Measurement Methods, Atmos. Environ., 22, 1519-1539, 1988

Hinds, W. C.: Aerosol Technology, Properties, Behavior and Measurement of Airborne Particles, New York, John Wiley and Sons, 1999.

Huang, G., Zhou, X. L., Deng, G. H., Qiao, H. C., and Civerolo, K.: Measurements of atmospheric nitrous acid and nitric acid, Atmos. Environ., 36, 2225-2235, 2002.

Huey, L. G., Dunlea, E. J., Lovejoy, E. R., Hanson, D. R., Norton, R. B., Fehsenfeld, F. C., and Howard, C. J.: Fast time response measurements of $\mathrm{HNO}_{3}$ in air with a chemical ionization mass spectrometer, J. Geophys. Res.-Atmos., 103, 3355-3360, 1998.

Jayne, J. T., Leard, D. C., Zhang, X. F., Davidovits, P., Smith, K A., Kolb, C. E., and Worsnop, D. R.: Development of an aerosol mass spectrometer for size and composition analysis of submicron particles, Aerosol Sci. Technol., 33, 49-70, 2000.

Jimenez, J. L., Jayne, J. T., Shi, Q., Kolb, C. E., Worsnop, D. R., Yourshaw, I., Seinfeld, J. H., Flagan, R. C., Zhang, X. F., Smith, K. A., Morris, J. W., and Davidovits, P.: Ambient aerosol sampling using the Aerodyne Aerosol Mass Spectrometer, J. Geophys. Res.-Atmos., 108, D7, 8425, doi:10.1029/2001JD00121, 2003.

Jongejan, P. A. C., Bai, Y., Veltkamp, A. C., Wyers, G. P., and Slanina, J.: An automated field instrument for the determination of acidic gases in air, Int. J. Environ. Anal. Chem., 66, 241-251, 1997.

Keuken, M. P., Schoonebeek, C. A. M., Wensveen-Louter, A., and Slanina, J.: Simultaneous Sampling of $\mathrm{NH}_{3}, \mathrm{HNO}_{3}, \mathrm{HCl}, \mathrm{SO}_{2}$ and $\mathrm{H}) 2 \mathrm{O}_{2}$ in Ambient Air by a Wet Annular Denuder System, Atmos. Environ., 22, 2541-2548, 1988.

Keuken, M. P., Waijers-Ijpelaan, A., Mols, J. J., Otjes, R. P., and Slanina, J.: The Determination of Ammonia in Ambient Air by an Automated Thermodenuder System, Atmos. Environ., 23, 2177-2185, 1989.

Khlystov, A., Wyers, G. P., and Slanina, J.: The Steam-Jet Aerosol Collector, Atmos. Environ., 29, 2229-2234, 1995.

Kirchner, W., Welter, F., Bongartz, A., Kames, J., Schweighoefer, S., and Schurath, U.: Trace Gas-Exchange at the Air-WaterInterface - Measurements of Mass Accommodation Coefficients, 
J. Atmos. Chem., 10, 427-449, 1990.

Kirkman, G. A., Gut, A., Ammann, C., Gatti, L. V., Cordova, A. M., Moura, M. A. L., Andreae, M. O., and Meixner, F. X.: Surface exchange of nitric oxide, nitrogen dioxide, and ozone at a cattle pasture in Rondonia, Brazil, J. Geophys. Res.-Atmos., 107, D20, 8083, doi:10.1029/2001JD000523, 2002.

Kitto, A. M. N. and Harrison, R. M.: Nitrous and Nitric-Acid Measurements at Sites in South-East England, Atmospheric Environment Part a-General Topics, 26, 235-241, 1992.

Kleffmann, J., Kurtenbach, R., Lörzer, J., Wiesen, P., Kalthoff, N., Vogel, B., and Vogel, H.: Measured and simulated vertical profiles of nitrous acid, Part I: Field measurements, Atmos. Environ., 37, 2949-2955, 2003.

Klockow, D., Niessner, R., Malejczyk, M., Kiendl, H., Vomberg, B., Keuken, M. P., Waijers-Ijpelaan, A., and Slanina, J.: Determination of Nitric-Acid and Ammonium-Nitrate by Means of a Computer-Controlled Thermodenuder System, Atmos. Environ., 23, 1131-1138, 1989.

Lee, S. H., Murphy, D. M., Thomson, D. S., and Middlebrook, A. M.: Chemical components of single particles measured with Particle Analysis by Laser Mass Spectrometry (PALMS) during the Atlanta SuperSite Project: Focus on organic/sulfate, lead, soot, and mineral particles, J. Geophys. Res.-Atmos., 107, D1-D2, doi:10.1029/2000JD000011, 2002.

Lefer, B. L., Talbot, R. W., and Munger, J. W.: Nitric acid and ammonia at a rural northeastern US site, J. Geophys. Res.-Atmos., 104, 1645-1661, 1999.

Lindgren, P. F.: Diffusion Scrubber-Ion Chromatography for the Measurement of Trace Levels of Atmospheric $\mathrm{HCl}$, Atmospheric Environment Part a-General Topics, 26, 43-49, 1992.

Mallina, R. V., Wexler, A. S., Rhoads, K. P., and Johnston, M. V.: High speed particle beam generation: A dynamic focusing mechanism for selecting ultrafine particles, Aerosol Sci. Technol., 33, 87-104, 2000.

Marshall, G. B. and Dimmock, N. A.: Determination of NitricAcid in Ambient Air Using Diffusion Denuder Tubes, Talanta, 39, 1463-1469, 1992

Matusca, P., Schwarz, B., and Bächmann, K.: Measurements of Diurnal Concentration Variations of Gaseous $\mathrm{HCl}$ in Air in the Subnanogram Range, Atmos. Environ., 18, 1667-1675, 1984.

Mauldin, R. L., Tanner, D. J., and Eisele, F. L.: A new chemical ionization mass spectrometer technique for the fast measurement of gas phase nitric acid in the atmosphere, J. Geophys. Res.-Atmos., 103, 3361-3367, 1998.

Mehlmann, A., and Warneck, P.: Atmospheric Gaseous $\mathrm{HNO}_{3}$ Particulate Nitrate, and Aerosol-Size Distributions of Major Ionic Species at a Rural Site in Western Germany, Atmos. Environ., 29, 2359-2373, 1995.

Meixner, F. X.: Surface exchange of odd nitrogen oxides, Nova Acta Leopoldina, 70, 299-348, 1994.

Mills, I., Cvitas, T., Homann, K., and Kuchitsu, K.: Quantities, Units and Symbols in Physical Chemistry, Oxford, Blackwell Scientific Publications, 1993.

Neuman, J. A., Huey, L. G., Ryerson, T. B., and Fahey, D. W.: Study of Inlet Materials for Sampling Atmospheric Nitric Acid, Environ. Sci. Technol., 33, 1133-1136, 1999.

Oms, M. T., Jongejan, P. A. C., Veltkamp, A. C., Wyers, G. P., and Slanina, J.: Continuous monitoring of atmospheric $\mathrm{HCl}, \mathrm{HNO}_{2}$, $\mathrm{HNO}_{3}$, and $\mathrm{SO}_{2}$, by wet-annular denuder air sampling with on- line chromatographic analysis, Int. J. Environ. Anal. Chem., 62, 207-218, 1996.

Orsini, D. A., Ma, Y. L., Sullivan, A., Sierau, B., Baumann, K., and Weber, R. J.: Refinements to the particle-into-liquid sampler (PILS) for ground and airborne measurements of water soluble aerosol composition, Atmos. Environ., 37, 1243-1259, 2003.

Papenbrock, T., and Stuhl, F.: A Laser-Photolysis FragmentFluorescence (LPFF) Method for the Detection of Gaseous Nitric-Acid in Ambient Air, J. Atmos. Chem., 10, 451-469, 1990.

Papenbrock, T. and Stuhl, F.: Measurement of Gaseous Nitric-Acid by a Laser-Photolysis Fragment-Fluorescence (LPFF) Method in the Black-Forest and at the North-Sea Coast, Atmos. Environ. Part A - General Topics, 25, 2223-2228, 1991.

Parrish, D. D., Norton, R. B., Bollinger, M. J., Liu, S. C., Murphy, P. C., Albritton, D. L., Fehsenfeld, F. C., and Huebert, B. J.: Measurements of $\mathrm{HNO}_{3}$ and $\mathrm{NH}_{3}$-Particulates at a Rural Site in the Colorado Mountains, J. Geophys. Res.-Atmos., 91, 53795393, 1986.

Perner, D. and Platt, U.: Detection of Nitrous-Acid in the Atmosphere by Differential Optical-Absorption, Geophys. Res. Lett., 6, 917-920, 1979.

Perrino, C., Desantis, F., and Febo, A.: Uptake of Nitrous-Acid and Nitrogen-Oxides by Nylon Surfaces - Implications for NitricAcid Measurement, Atmos. Environ., 22, 1925-1930, 1988.

Philips, D. A. and Dasgupta, P. K.: A Diffusion Scrubber for the Collection of Gaseous Nitric-Acid, Sep. Sci. Technol., 22, 1255$1267,1987$.

Pio, C. A. and Harrison, R. M.: The Equilibrium of AmmoniumChloride Aerosol with Gaseous Hydrochloric-Acid and Ammonia under Tropospheric Conditions, Atmos. Environ., 21, 1243 $1246,1987$.

Plane, J. M. C. and Nien, C. F.: Differential Optical-Absorption Spectrometer for Measuring Atmospheric Trace Gases, Rev. Sci. Instrum., 63, 1867-1876, 1992.

Ponche, J. L., George, C., and Mirabel, P.: Mass-Transfer at the AirWater-Interface - Mass Accommodation Coefficients of $\mathrm{SO}_{2}$, $\mathrm{HNO}_{3}, \mathrm{NO}_{2}$ and $\mathrm{NH}_{3}$, J. Atmos. Chem., 16, 1-21, 1993.

Possanzini, M., De Santis, F., and Di Palo, V.: Measurements of nitric acid and ammonium salts in lower Bavaria, Atmos. Environ. 33, 3597-3602, 1999.

Rapsomanikis, S., Wake, M., Kitto, A. M. N., and Harrison, R. M.: Analysis of Atmospheric Ammonia and Particulate Ammonium by a Sensitive Fluorescence Method, Environ. Sci. Technol., 22, 948-952, 1988.

Roberts, M. C., Andreae, M. O., Zhou, J. C., and Artaxo, P.: Cloud condensation nuclei in the Amazon Basin: "Marine" conditions over a continent?, Geophys. Res. Lett., 28, 2807-2810, 2001.

Rodgers, M. O. and Davis, D. D.: A UV-Photofragmentation LaserInduced Fluorescence Sensor for the Atmospheric Detection of HONO, Environ. Sci. Technol., 23, 1106-1112, 1989.

Sanhueza, E. and Garaboto, A.: Gaseous $\mathrm{HCl}$ at a remote tropical continental site, Tellus Ser. B-Chem. Phys. Meteorol., 54, 412415, 2002.

Schwartz, S. E. and Warneck, P.: Units for Use in Atmospheric Chemistry, Pure Appl. Chem., 67, 1377-1406, 1995.

Simon, P. K. and Dasgupta, P. K.: Wet Effluent Denuder Coupled Liquid Ion Chromatography Systems - Annular and ParallelPlate Denuders, Anal. Chem., 65, 1134-1139, 1993. 
Simon, P. K. and Dasgupta, P. K.: Continuous Automated Measurement of Gaseous Nitrous and Nitric-Acids and Particulate Nitrite and Nitrate, Environ. Sci. Technol., 29, 1534-1541, 1995a.

Simon, P. K. and Dasgupta, P. K.: Continuous Automated Measurement of the Soluble Fraction of Atmospheric Particulate Matter, Anal. Chem., 67, 71-78, 1995b.

Simon, P. K., Dasgupta, P. K., and Vecera, Z.: Wet Effluent Denuder Coupled Liquid Ion Chromatography Systems, Anal. Chem., 63, 1237-1242, 1991.

Slanina, J., de Wild, P. J., and Wyers, G. P.: The application of denuder systems to the analysis of atmospheric components, New York, John Wiley and Sons, 1992.

Slanina, J., ten Brink, H. M., Otjes, R. P., Even, A., Jongejan, P., Khlystov, A., Waijers-Ijpelaan, A., and Hu, M.: The continuous analysis of nitrate and ammonium in aerosols by the steam jet aerosol collector (SJAC): extension and validation of the methodology, Atmos. Environ., 35, 2319-2330, 2001.

Slanina, J. and Wyers, G. P.: Monitoring of Atmospheric Components by Automatic Denuder Systems, Fresenius J. Anal. Chem., 350, 467-473, 1994.

Solomon, P., Baumann, K., Edgerton, E., Tanner, R., Eatough, D., Modey, W., Marin, H., Savoie, D., Natarajan, S., Meyer, M. B., and Norris, G.: Comparison of integrated samplers for mass and composition during the 1999 Atlanta Supersites project, J. Geophys. Res.-Atmos., 108, D7, 8423, doi:10.1029/2001JD001218, 2003.

Solomon, P. A., Larson, S. M., Fall, T., and Cass, G. R.: Basinwide Nitric-Acid and Related Species Concentrations Observed During the Claremont Nitrogen Species Comparison Study, Atmos. Environ., 22, 1587-1594, 1988.

Spicer, C.W., and Schumacher, P.M.: Particulate Nitrate - Laboratory and Field Studies of Major Sampling Interferences, Atmos. Environ., 13, 543-552, 1979.

Spicer, C. W., Howes, J. E., Bishop, T. A., Arnold, L. H., and Stevens, R. K.: Nitric-Acid Measurement Methods - an Intercomparison, Atmos. Environ., 16, 1487-1500, 1982.

Spindler, G., Hesper, J., Brüggemann, E., Dubois, R., Müller, T., and Herrmann, H.: Wet annular denuder measurements of nitrous acid: laboratory study of the artefact reaction of NO2 with $\mathrm{S}(\mathrm{IV})$ in aqueous solution and comparison with field measurements, Atmos. Environ., 37, 2643-2662, 2003.

Stelson, A. W. and Seinfeld, J. H.: Relative-Humidity and Temperature-Dependence of the Ammonium-Nitrate Dissociation-Constant, Atmos. Environ., 16, 983-992, 1982.

Stolzenburg, M. R. and Hering, S. V.: Method for the automated measurement of fine particle nitrate in the atmosphere, Environ. Sci. Technol., 34, 907-914, 2000.

Stutz, J., Alicke, B., and Neftel, A.: Nitrous acid formation in the urban atmosphere: Gradient measurements of $\mathrm{NO}_{2}$ and $\mathrm{HONO}$ over grass in Milan, Italy, J. Geophys. Res.-Atmos., 107, D22, 8192, doi:10.1029/2001JD000390, 2002.

Taira, M. and Kanda, Y.: Wet Effluent Diffusion Denuder for Sampling of Atmospheric Gaseous Nitric-Acid, Anal. Chem., 65, 3171-3173, 1993.
Tanner, R. L., Kelly, T. J., Dezaro, D. A., and Forrest, J.: A Comparison of Filter, Denuder, and Real-Time Chemi-Luminescence Techniques for Nitric-Acid Determination in Ambient Air, Atmos. Environ., 23, 2213-2222, 1989.

Van Doren, J. M., Watson, L. R., Davidovits, P., Worsnop, D. R., Zahniser, M. S., and Kolb, C. E.: Temperature-Dependence of the Uptake Coefficients of $\mathrm{HNO}_{3}, \mathrm{HCl}$, and $\mathrm{N}_{2} \mathrm{O}_{5}$ by Water Droplets, Journal of Physical Chemistry, 94, 3265-3269, 1990.

Vecera, Z. and Dasgupta, P. K.: Measurement of Atmospheric Nitric and Nitrous Acids with a Wet Effluent Diffusion Denuder and Low-Pressure Ion Chromatography Postcolumn Reaction Detection, Anal. Chem., 63, 2210-2216, 1991.

Wang, L. M. and Zhang, J. S.: Detection of nitrous acid by cavity ring down spectroscopy, Environ. Sci. Technol., 34, 4221-4227, 2000.

Weber, R., Orsini, D., Duan, Y., Baumann, K., Kiang, C. S., Chameides, W., Lee, Y. N., Brechtel, F., Klotz, P., Jongejan, P., ten Brink, H., Slanina, J., Boring, C. B., Genfa, Z., Dasgupta, P., Hering, S., Stolzenburg, M., Dutcher, D. D., Edgerton, E., Hartsell, B., Solomon, P., and Tanner, R.: Intercomparison of near real time monitors of PM2.5 nitrate and sulfate at the U.S. Environmental Protection Agency Atlanta Supersite, J. Geophys. Res.-Atmos., 108, D7, 8421, doi:10.1029/2001JD001220, 2003.

Weber, R. J., Orsini, D., Daun, Y., Lee, Y. N., Klotz, P. J., and Brechtel, F.: A particle-into-liquid collector for rapid measurement of aerosol bulk chemical composition, Aerosol Sci. Technol., 35, 718-727, 2001.

Williams, E. J., Sandholm, S. T., Bradshaw, J. D., Schendel, J. S., Langford, A. O., Quinn, P. K., Lebel, P. J., Vay, S. A., Roberts, P. D., Norton, R. B., Watkins, B. A., Buhr, M. P., Parrish, D. D., Calvert, J. G., and Fehsenfeld, F. C.: An Intercomparison of 5 Ammonia Measurement Techniques, J. Geophys. Res.-Atmos., 97, 11 591-11611, 1992.

Winer, A. M., and Biermann, H. W.: Long Pathlength Differential Optical-Absorption Spectroscopy (DOAS) Measurements of Gaseous $\mathrm{HONO}, \mathrm{NO}_{2}$ and $\mathrm{HCHO}$ in the California South Coast Air Basin, Res. Chem. Intermed., 20, 423-445, 1994.

Wyers, G. P., Otjes, R. P., and Slanina, J.: A Continuous-Flow Denuder for the Measurement of Ambient Concentrations and Surface-Exchange Fluxes of Ammonia, Atmospheric Environment Part a-General Topics, 27, 2085-2090, 1993.

Zellweger, C., Ammann, M., Hofer, P., and Baltensperger, U.: $\mathrm{NO}_{\mathrm{y}}$ speciation with a combined wet effluent diffusion denuderaerosol collector coupled to ion chromatography, Atmos. Environ., 33, 1131-1140, 1999.

Zhang, J., Chameides, W. L., Weber, R., Cass, G., Orsini, D., Edgerton, E., Jongejan, P., and Slanina, J.: An evaluation of the thermodynamic equilibrium assumption for fine particulate composition: Nitrate and ammonium during the 1999 Atlanta Supersite Experiment, J. Geophys. Res.-Atmos., 108, D21, 8414, doi:10.1029/2001JD001592, 2002.

Zhou, X. L., Civerolo, K., Dai, H. P., Huang, G., Schwab, J., and Demerjian, K.: Summertime nitrous acid chemistry in the atmospheric boundary layer at a rural site in New York State, J. Geophys. Res.-Atmos., 107, D21, 4590, doi:10.1029/2001JD001539, 2002. 